Prepared in cooperation with the U.S. Army Corps of Engineers as part of the U.S. Geological Survey Greater Everglades Priority Ecosystem Science

\title{
Flow Characteristics and Salinity Patterns of Tidal Rivers within the Northern Ten Thousand Islands, Southwest Florida, Water Years 2007-14
}

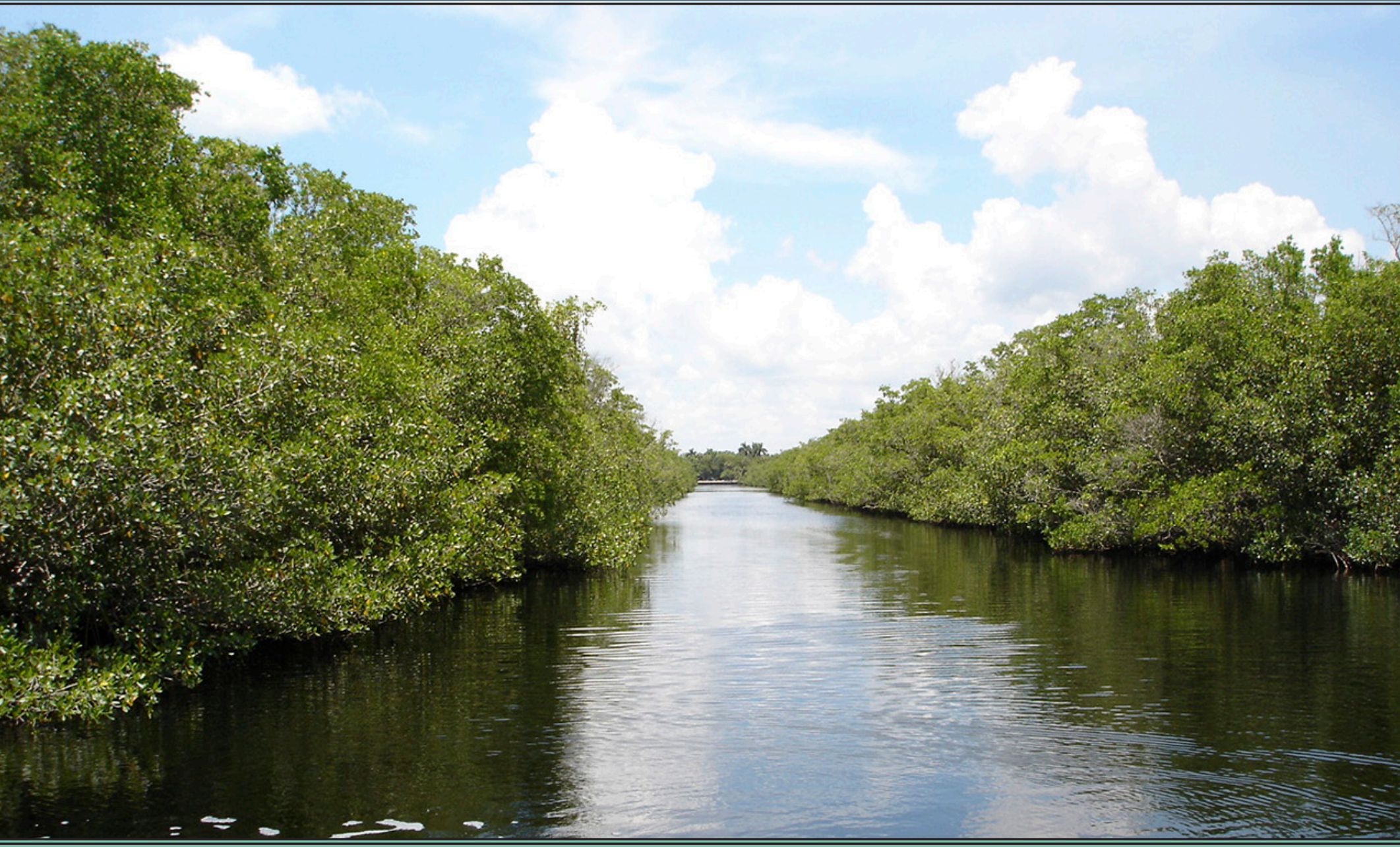

Scientific Investigations Report 2016-5158 
Cover. Mangroves along Blackwater River, Collier-Seminole State Park. Photograph by Lars Soderqvist, U.S. Geological Survey. 


\section{Flow Characteristics and Salinity Patterns of Tidal Rivers within the Northern Ten Thousand Islands, Southwest Florida, Water Years 2007-14}

By Amanda C. Booth and Lars E. Soderqvist

Prepared in cooperation with the U.S. Army Corps of Engineers as part of the U.S. Geological Survey Greater Everglades Priority Ecosystem Science

Scientific Investigations Report 2016-5158 


\title{
U.S. Department of the Interior SALLY JEWELL, Secretary
}

\section{U.S. Geological Survey Suzette M. Kimball, Director}

\author{
U.S. Geological Survey, Reston, Virginia: 2016
}

For more information on the USGS - the Federal source for science about the Earth, its natural and living resources, natural hazards, and the environment—visit http://www.usgs.gov or call 1-888-ASK-USGS.

For an overview of USGS information products, including maps, imagery, and publications, visit http://store.usgs.gov.

Any use of trade, firm, or product names is for descriptive purposes only and does not imply endorsement by the U.S. Government.

Although this information product, for the most part, is in the public domain, it also may contain copyrighted materials as noted in the text. Permission to reproduce copyrighted items must be secured from the copyright owner.

Suggested citation:

Booth, A.C., and Soderqvist, L.E., 2016, Flow characteristics and salinity patterns of tidal rivers within the northern Ten Thousand Islands, southwest Florida, water years 2007-14: U.S. Geological Survey Scientific Investigations Report 2016-5158, 22 p., https://doi.org/10.3133/sir20165158.

ISSN 2328-0328 (online)

Title page photograph. Faka Union Boundary water-quality station. Photograph by Lars Soderqvist, U.S. Geological Survey, June 2016. 


\section{Acknowledgments}

The authors wish to thank Patrick Pitts with the U.S. Fish and Wildlife Service and Amanda McDonald with the South Florida Water Management District for their review of this report. The authors also wish to thank Andrew Erickson, Marty Berry, Ryan Hollins, and Drew Milewski of the U.S. Geological Survey Caribbean-Florida Water Science Center, Ft. Myers office, for their many hours of hard work in the field collecting the data presented in this report and for computing and verifying flow and salinity data. 


\section{Contents}

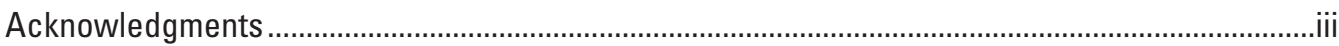

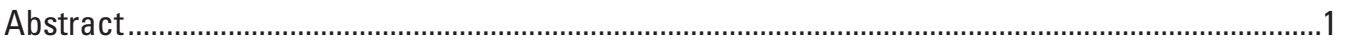

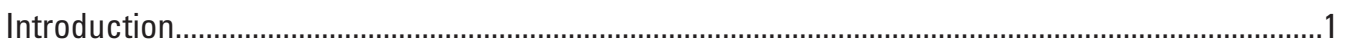

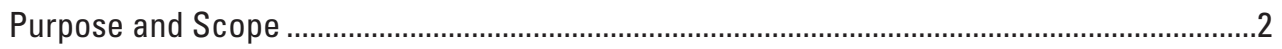

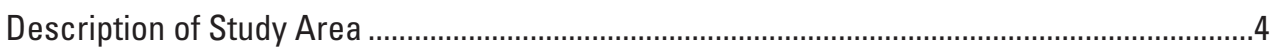

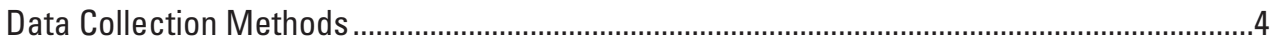

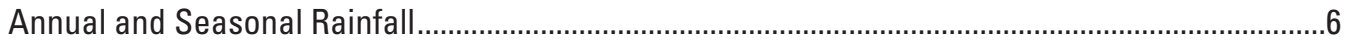

Annual and Seasonal Flow Characteristics of Tidal Rivers ..........................................................

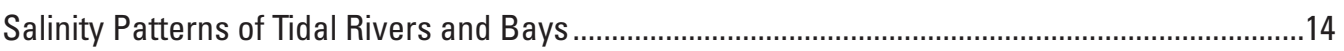

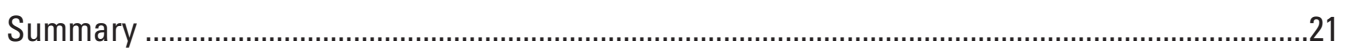

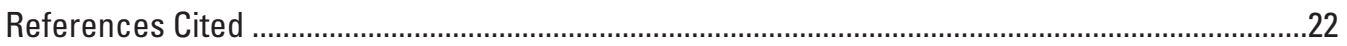

\section{Figures}

1. Map showing the northern Ten Thousand Islands estuary study area

2. Map showing streamflow and water-quality stations in the northern Ten Thousand Islands estuary.

3. Photograph showing streamflow and water-quality station at Faka Union River, May 2006

4. Graph showing annual, seasonal, and average rainfall in the northern Ten Thousand Islands, water years 2007-14, calculated using data obtained from South Florida Water Management District rainfall stations.

5. Graph showing annual flow at Faka Union River, water years 2008 and $2011-14$............8

6. Graphs showing annual flow at tidal tributaries, water years 2008 and 2011-14:

East River, Little Wood River, Pumpkin River, and Blackwater River ..

7. Graph showing flow contributed by East River, Faka Union River, Pumpkin River, and Blackwater River, water years 2008, 2011, and $2014 .$.

8. Graphs showing annual flow volume compared to rainfall by water year:

East River, Faka Union River, Pumpkin River, and Blackwater River.

9. Graphs showing wet season total flows, water years 2008 and 2011-14, including and excluding the Faka Union River

10. Graphs showing dry season total flows, water years 2008 and 2011-14, including and excluding the Faka Union River

11. Graphs showing monthly flow volume at Faka Union River, East River, Little Wood River, Pumpkin River, and Blackwater River, water years 2007-14, and monthly flow volume at East River, Little Wood River, Pumpkin River, and Blackwater River, water years 2007-14

12. Boxplots showing salinity data by site and water year: East River, Little Wood River, Pumpkin River, Palm River, Blackwater River, Faka Union River, and Faka Union Boundary....

13. Graphs showing salinity duration curves by site and water year: East River, Little Wood River, Pumpkin River, Blackwater River, Palm River, Faka Union River, and Faka Union Boundary. 
14. Graphs showing relation between annual mean salinity values and annual rainfall: East River, Faka Union River, Pumpkin River, and Blackwater River

15. Graph showing monthly mean salinity values by site, July 2006 to September 2014, Ten Thousand Islands estuary area

\section{Tables}

1. USGS station names, station numbers, parameters, and dates of operation, northern Ten Thousand Islands estuary, Florida

2. Annual and seasonal rainfall totals in the northern Ten Thousand Islands, water years 2007-14.

3. Percentage of total monthly flow that was negative during water years 2008 and 2011-14 in the northern Ten Thousand Islands estuary

4. Annual mean and instantaneous minimum and maximum salinity values, water years 2007-14, in the northern Ten Thousand Islands estuary

5. Percentage of instantaneous salinity values greater than or equal to 35.0 parts per thousand, water years 2007-14, in the northern Ten Thousand Islands estuary.

6. Maximum and minimum monthly mean salinity values, water years $2007-14$, in the northern Ten Thousand Islands estuary.

\section{Conversion Factors}

U.S. customary units to International System of Units

\begin{tabular}{|c|c|c|}
\hline Multiply & By & To obtain \\
\hline \multicolumn{3}{|c|}{ Length } \\
\hline inch (in.) & 2.54 & centimeter $(\mathrm{cm})$ \\
\hline foot $(\mathrm{ft})$ & 0.3048 & meter $(\mathrm{m})$ \\
\hline mile (mi) & 1.609 & kilometer $(\mathrm{km})$ \\
\hline \multicolumn{3}{|c|}{ Area } \\
\hline acre & 4,047 & square meter $\left(\mathrm{m}^{2}\right)$ \\
\hline acre & 0.004047 & square kilometer $\left(\mathrm{km}^{2}\right)$ \\
\hline square foot $\left(\mathrm{ft}^{2}\right)$ & 0.09290 & square meter $\left(\mathrm{m}^{2}\right)$ \\
\hline square mile $\left(\mathrm{mi}^{2}\right)$ & 2.590 & square kilometer $\left(\mathrm{km}^{2}\right)$ \\
\hline \multicolumn{3}{|c|}{ Flow rate } \\
\hline acre-foot per day (acre-ft/d) & 0.01427 & cubic meter per second $\left(\mathrm{m}^{3} / \mathrm{s}\right)$ \\
\hline acre-foot per year (acre-ft/yr) & 1,233 & cubic meter per year $\left(\mathrm{m}^{3} / \mathrm{yr}\right)$ \\
\hline foot per second (ft/s) & 0.3048 & meter per second $(\mathrm{m} / \mathrm{s})$ \\
\hline cubic foot per second $\left(\mathrm{ft}^{3} / \mathrm{s}\right)$ & 0.02832 & cubic meter per second $\left(\mathrm{m}^{3} / \mathrm{s}\right)$ \\
\hline
\end{tabular}

\section{Datums}

Vertical coordinate information is referenced to the National Geodetic Vertical Datum of 1929 (NGVD 29).

Horizontal coordinate information is referenced to the North American Datum of 1983 (NAD 83).

Elevation, as used in this report, refers to the distance above the vertical datum. 


\section{Abbreviations}

$\begin{array}{ll}\text { ppt } & \text { parts per thousand } \\ \text { SFWMD } & \text { South Florida Water Management District } \\ \text { SGGE } & \text { Southern Golden Gate Estates } \\ \text { TS } & \text { Tropical Storm } \\ \text { TTI } & \text { Ten Thousand Islands } \\ \text { USGS } & \text { U.S. Geological Survey }\end{array}$




\title{
Flow Characteristics and Salinity Patterns of Tidal Rivers within the Northern Ten Thousand Islands, Southwest Florida, Water Years 2007-14
}

\author{
By Amanda C. Booth and Lars E. Soderqvist
}

\section{Abstract}

Freshwater flow to the Ten Thousand Islands estuary has been altered by the construction of the Tamiami Trail and the Southern Golden Gate Estates. The Picayune Strand Restoration Project, which is associated with the Comprehensive Everglades Restoration Plan, has been implemented to improve freshwater delivery to the Ten Thousand Islands estuary by removing hundreds of miles of roads, emplacing hundreds of canal plugs, removing exotic vegetation, and constructing three pump stations. Quantifying the tributary flows and salinity patterns prior to, during, and after the restoration is essential to assessing the effectiveness of upstream restoration efforts.

Tributary flow and salinity patterns during preliminary restoration efforts and prior to the installation of pump stations were analyzed to provide baseline data and preliminary analysis of changes due to restoration efforts. The study assessed streamflow and salinity data for water years ${ }^{1} 2007-2014$ for the Faka Union River (canal flow included), East River, Little Wood River, Pumpkin River, and Blackwater River. Salinity data from the Palm River and Faka Union Boundary waterquality stations were also assessed.

Faka Union River was the dominant contributor of freshwater during water years 2007-14 to the Ten Thousand Islands estuary, followed by Little Wood and East Rivers. Pumpkin River and Blackwater River were the least substantial contributors of freshwater flow. The lowest annual flow volumes, the highest annual mean salinities, and the highest percentage of salinity values greater than 35 parts per thousand (ppt) occurred in water year 2011 at all sites with available data, corresponding with the lowest annual rainfall during the study. The highest annual flow volumes and the lowest percentage of salinities greater than 35 ppt occurred in water year 2013 for all sites with available data, corresponding with the highest rainfall during the study.

\footnotetext{
${ }^{1}$ Water year is defined as the 12-month period from October 1 , for any given year, through September 30 of the following year.
}

In water year 2014, the percentage of monitored annual flow contributed by East River increased and the percentage of flow contributed by Faka Union River decreased, compared to the earlier years. No changes in annual flow occurred at any sites west of Faka Union River. No changes in the relative flow contributions were observed during the wet season; however, the relative amounts of streamflow increased during the dry season at East River in 2014. East River had only 1 month of negative flow in 2014 compared to 6 months in 2011 and 7 months in 2008. Higher dry season flows in East River may be in response to restoration efforts. The sites to the west of Faka Union River had higher salinities on average than Faka Union River and East River. Faka Union River had the highest range in salinities, and Faka Union Boundary had the lowest range in salinities. Pumpkin River was the tributary with the lowest range in salinities.

\section{Introduction}

The Ten Thousand Islands (TTI) estuary of southwest Florida (fig. 1) is part of the largest expanse of mangrove forest in the United States and provides valuable fish and wildlife habitat. The TTI estuary is home to large populations of wading birds, including herons, egrets, rosette spoonbills, and wood storks. At least 200 species of fish inhabit the area (U.S. Fish and Wildlife Service, 2008), including the endangered smalltooth sawfish (Simpfendorfer and others, 2010). More than 10 percent of Florida's manatee population uses the TTI estuary throughout the year (U.S. Fish and Wildlife Service, 2008). The environmental health and ecological functioning of the TTI estuary is dependent upon the quality, quantity, timing, and distribution of freshwater deliveries to the estuary.

Historically the TTI estuary received its freshwater from sheet flow from the Fakahatchee Strand and Picayune Strand watersheds through a natural course of sloughs, wetlands, marshes, and rivers. This historical freshwater sheet flow was altered by the construction of U.S. Highway 41 (fig. 1), also known as the Tamiami Trail, and a number of features relating to the development of the once-planned residential community 
of Southern Golden Gate Estates (SGGE) (U.S. Army Corps of Engineers, 1998). The Tamiami Trail was completed in 1928, creating a blockage to the natural drainage of Picayune and Fakahatchee Strands (U.S. Army Corps of Engineers, 1998). A borrow canal was dug along the north side of the Tamiami Trail, and water is conveyed under the road at a number of bridges and culverts. In 2006, nine new culverts were constructed under the Tamiami Trail to allow restored sheet flow to the TTI estuary as part of the Tamiami Trail Culverts project (U.S. Army Corps of Engineers, 2008).

A number of features were constructed during the 1960s as part of the 86-square-mile SGGE development, including the Faka Union Canal System. The Faka Union Canal System consists of four canals (Miller Canal, Faka Union Canal, Merritt Canal, and Prairie Canal) that were built to drain the area for the SGGE project (fig. 1). Several roads, with adjacent drainage ditches, diverted sheet flow into the Faka Union Canal System, accelerating drainage within the watershed and reducing wetland inundation, aquifer recharge, and base flow into the estuaries. Approximately 48 miles (mi) of canals were dredged, and $270 \mathrm{mi}$ of roads were constructed (South Florida Water Management District, 2015a) prior to the economic failure of the now-defunct SGGE.

Seasonal salinity maps produced by the U.S. Geological Survey (USGS) during 2007-10 documented the patterns of altered freshwater flows to the estuary. During the wet season, Faka Union Canal was a point source of freshwater, as indicated by large freshwater plumes. In addition, higher salinities were often observed in the inner bays west of the Faka Union Canal, particularly Pumpkin Bay, compared to the inner bays east of the Faka Union Canal (Soderqvist and Patino, 2010).

During 2008-10, discharge flowing to the estuary was computed by the USGS at all of the bridges and culverts along the Tamiami Trail between County Road 92 and State Road 29, excluding the Faka Union Canal, which is monitored by the South Florida Water Management District (SFWMD). The Faka Union Canal accounted for more than half (58-62 percent) of the flow during this period. An average of 9 percent of the flow under the Tamiami Trail between County Road 92 and State Road 29, including the Faka Union Canal, came from west of the Faka Union Canal during 2008-10 (Booth and others, 2014).

The goal of the Picayune Strand Restoration Project, a Comprehensive Everglades Restoration Plan project authorized by Congress in 2007, is to "restore historic hydroperiods and sheet-flow patterns in the study area, to the extent possible, while maintaining the existing levels of flood protection for areas north of the SGGE" (U.S. Army Corps of Engineers, 2004). The project calls for the removal of $260 \mathrm{mi}$ of roads, the placement of 100 plugs within $48 \mathrm{mi}$ of existing canals, and the removal of exotic vegetation. In addition, three pump stations at the Merritt, Faka Union, and Miller Canals are to be constructed with downstream spreader channels to restore sheet flow through the area while maintaining flood control capacity for communities to the north (U.S. Army Corps of Engineers, 2008). The filling of the Prairie Canal began in
2004 and was completed in 2012. The roads and logging trams to the east of the Merritt Canal were degraded or removed during 2006-12. Removal of the roads and logging trams between Merritt and Faka Union Canals began in 2010, and the majority were removed by the end of 2012. Plugging of the Merritt Canal began in the fall of 2014 (Chuirazzi and others, 2015), and $10 \mathrm{mi}$ of the Merritt Canal were plugged as of June 2015. In June 2015, the Merritt Pump Station began operation. The Merritt Pump Station is capable of pumping 810 cubic feet per second to provide water for restoration efforts and flood control to the north (South Florida Water Management District, 2015a). Road removal between Faka Union Canal and Miller Canal began in late 2011. By mid-2014, the majority of the road removal between these two canals was completed. The Faka Union Pump Station was scheduled to begin operation in winter 2015; however, the Faka Union Canal will not be plugged until 2018. The construction of the Miller Canal Pump Station began in 2014 and is projected to be completed in 2017. The plugging of the Miller Canal and removal of roads west of it is scheduled for 2017-18 (Chuirazzi and others, 2015). Quantifying the tributary flows and salinity patterns, before and after these changes, is essential to assessing the effectiveness of restoration efforts.

\section{Purpose and Scope}

The purpose of this report is to describe the flow characteristics and salinity patterns within the northern parts of the TTI estuary between water years 2007 and 2014. Some salinity data from 2006 are also included in the discussion for Faka Union River. All data presented within this report are referenced to water years (October 1 of the previous calendar year to September 30 of the current calendar year). For example, water year 2012 is from October 1, 2011, to September 30, 2012.

The report primarily focuses on areas within the TTI National Wildlife Refuge and Collier-Seminole State Park (fig. 1). The report characterizes tributary flow and salinity patterns prior to the installation of pump stations as part of the Picayune Strand Restoration Project, providing the baseline data needed to analyze changes due to restoration efforts.

Flow and salinity data are presented and discussed for Faka Union River, Little Wood River, Pumpkin River, East River, and Blackwater River. Salinity data are also presented and discussed for the Palm River and Faka Union Boundary. Data are available for download from the National Water Information System Web interface (NWISWeb) (U.S. Geological Survey, 2015). Annual and seasonal flow volumes, seasonal patterns in flow, percentage of monitored flow contribution, and the effect of annual variations in rainfall on flow are discussed. Additionally, the highest and lowest annual mean salinities at tidal rivers and bays, instantaneous salinities, percentage of salinities less than or greater than 35 parts per thousand (ppt), and the effects of annual variations on salinity are described. 


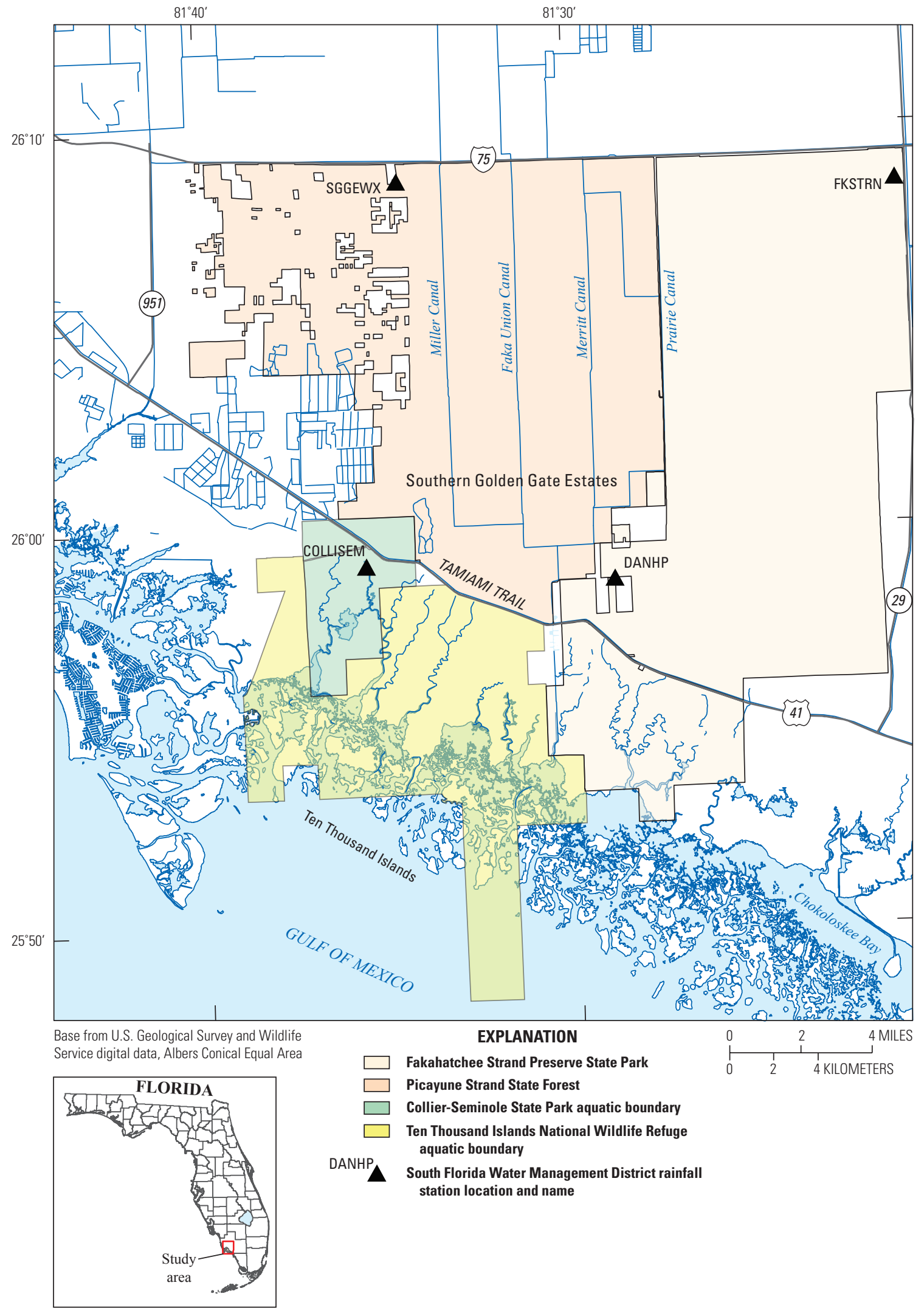

Figure 1. The northern Ten Thousand Islands estuary study area. 


\section{Description of Study Area}

The TTI estuary is a shallow, subtropical estuarine system that consists of numerous bays separated from the Gulf of Mexico by many small mangrove islands and tidal passes. Ten major rivers contribute freshwater to the northern TTI; from east to west they are the Ferguson River, East River, Fakahatchee River, Faka Union River, Wood River, Little Wood River, Pumpkin River, Whitney River, Blackwater River and Palm River (fig. 2). Flow to these rivers is controlled by topography and canal inputs (McCoy, 1972). The Faka Union Canal is controlled by a fixed crest weir with an elevation of 2 feet (ft) above the National Geodetic Vertical Datum of 1929 (South Florida Water Management District, 2013). The area receives semidiurnal mixed tides with a range of approximately $3 \mathrm{ft}$.

The climate is subtropical, with an average annual rainfall of 54 inches (in.) (Chuirazzi and others, 2015). The majority of the rainfall occurs during June through October. Summer rainfalls are typically short, intense, and frequent. Winter rainfalls are typically associated with weather fronts and are longer, less intense, and not as frequent (McCoy, 1972).

\section{Data Collection Methods}

Stage and water quality were measured at seven sites within the TTI estuary (table 1; figs. 2 and 3). In addition, flow rate and flow volume (discharge) were measured at five of the sites. Stage data were collected by using shaft encoders or pressure sensors. Acoustic Doppler velocity meters provided continuous measurements of index velocity. Measurements were made over a wide range of conditions, on approximately 6 days per year using acoustic Doppler current profilers. The index velocity method, which uses the relation between the mean channel velocity (as measured by the acoustic Doppler current profiler) and the index velocity (as measured by the acoustic Doppler velocity meter), was used to compute

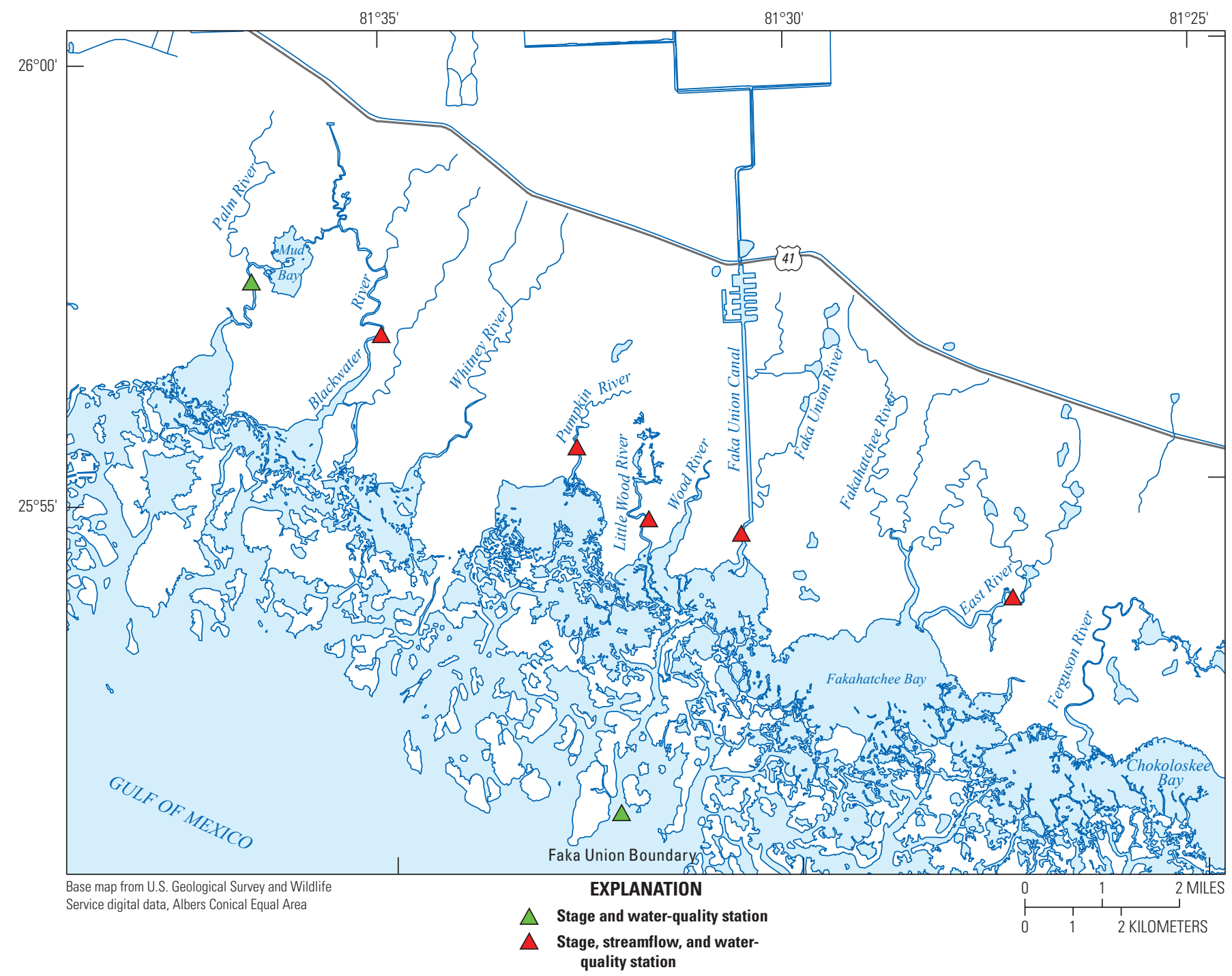

Figure 2. Streamflow and water-quality stations in the northern Ten Thousand Islands estuary. 
Table 1. USGS station names, station numbers, parameters, and dates of operation, northern Ten Thousand Islands estuary, Florida.

[USGS, U.S. Geological Survey; - , no data collected at this location]

\begin{tabular}{|c|c|c|c|c|c|c|}
\hline $\begin{array}{l}\text { USGS station } \\
\text { name }\end{array}$ & $\begin{array}{c}\text { USGS station } \\
\text { number }\end{array}$ & Stage & $\begin{array}{l}\text { Near-surface } \\
\text { water quality }\end{array}$ & $\begin{array}{l}\text { Near-bottom } \\
\text { water quality }\end{array}$ & $\begin{array}{c}\text { Mid-depth } \\
\text { water quality }\end{array}$ & Discharge \\
\hline Faka Union River & 255432081303900 & $\begin{array}{l}\text { June } 30,2006 \text { to } \\
\text { September 30, } 2008 \\
\text { May } 11,2010 \text { to } \\
\text { present }\end{array}$ & $\begin{array}{l}\text { June } 30,2006 \text { to } \\
\text { September } 30,2008 \\
\text { May } 11,2010 \text { to } \\
\text { October } 4,2011\end{array}$ & $\begin{array}{l}\text { June } 30,2006 \text { to } \\
\text { September } 30,2008 \\
\text { May } 11,2010 \\
\text { to present }\end{array}$ & - & $\begin{array}{l}\text { June } 30,2006 \text { to } \\
\text { September } 30,2008 \\
\text { May } 12,2010 \text { to present }\end{array}$ \\
\hline Little Wood River & 255443081314700 & $\begin{array}{l}\text { February } 27,2007 \text { to } \\
\text { September } 30,2008 \\
\text { April 27, 2010 to } \\
\text { October 6, } 2011\end{array}$ & $\begin{array}{l}\text { February } 27,2007 \text { to } \\
\text { September } 30,2008 \\
\text { April 27, 2010 to } \\
\text { October 6, } 2011\end{array}$ & $\begin{array}{l}\text { February } 27,2007 \text { to } \\
\text { September } 30,2008 \\
\text { April } 27,2010 \text { to } \\
\text { October } 6,2011\end{array}$ & - & $\begin{array}{l}\text { February } 27,2007 \text { to } \\
\text { September } 30,2008 \\
\text { April 27, 2010 to } \\
\text { October 6, } 2011\end{array}$ \\
\hline Pumpkin River & 255534081324000 & $\begin{array}{l}\text { April 18, } 2007 \text { to } \\
\text { September } 30,2008 \\
\text { July 7, } 2010 \text { to present }\end{array}$ & $\begin{array}{l}\text { April 18, } 2007 \text { to } \\
\text { September } 30,2008 \\
\text { June } 3,2010 \text { to } \\
\text { October 5, } 2011\end{array}$ & $\begin{array}{l}\text { April 18, } 2007 \text { to } \\
\text { September } 30,2008 \\
\text { July 7, } 2010 \text { to present }\end{array}$ & - & $\begin{array}{l}\text { April 19, } 2007 \text { to } \\
\text { September 30, } 2008 \\
\text { July 7, } 2010 \text { to present }\end{array}$ \\
\hline East River & 255327081275900 & $\begin{array}{l}\text { April 24, } 2007 \text { to } \\
\text { September 30, } 2008 \\
\text { April 23, } 2010 \text { to } \\
\text { present }\end{array}$ & $\begin{array}{l}\text { April 24, } 2007 \text { to } \\
\text { September 30, } 2008 \\
\text { April 23, 2010 to } \\
\text { October 5, } 2011\end{array}$ & $\begin{array}{l}\text { April 24, } 2007 \text { to } \\
\text { September } 30,2008 \\
\text { April 23, } 2010 \text { to present }\end{array}$ & - & $\begin{array}{l}\text { April 24, } 2007 \text { to } \\
\text { September 30, } 2008 \\
\text { April 23, 2010 to } \\
\text { May 1, 2012 } \\
\text { October 28, } 2013 \\
\text { to present }\end{array}$ \\
\hline Blackwater River & 255654081350200 & $\begin{array}{l}\text { May 16, } 2007 \text { to } \\
\text { September } 30,2008 \\
\text { July 8, } 2010 \text { to present }\end{array}$ & $\begin{array}{l}\text { May } 16,2007 \text { to } \\
\text { September } 30,2008 \\
\text { May } 11,2010 \text { to } \\
\text { October } 4,2011\end{array}$ & $\begin{array}{l}\text { May 16, } 2007 \text { to } \\
\text { September } 30,2008 \\
\text { July 8, } 2010 \text { to present }\end{array}$ & - & $\begin{array}{l}\text { May 16, } 2007 \text { to } \\
\text { September } 30,2008 \\
\text { July 8, } 2010 \text { to present }\end{array}$ \\
\hline $\begin{array}{l}\text { Faka Union } \\
\text { Boundary }\end{array}$ & 255123081321300 & $\begin{array}{l}\text { July } 92010 \text { to } \\
\text { May } 1,2012\end{array}$ & - & - & $\begin{array}{l}\text { June } 13,2007 \text { to } \\
\text { September } 30,2008 \\
\text { July } 92010 \text { to } \\
\text { May } 1,2012\end{array}$ & - \\
\hline Palm River & 255732081363700 & $\begin{array}{l}\text { November } 17,2011 \\
\text { to present }\end{array}$ & - & - & $\begin{array}{l}\text { November 17, } 2011 \\
\text { to present }\end{array}$ & - \\
\hline
\end{tabular}




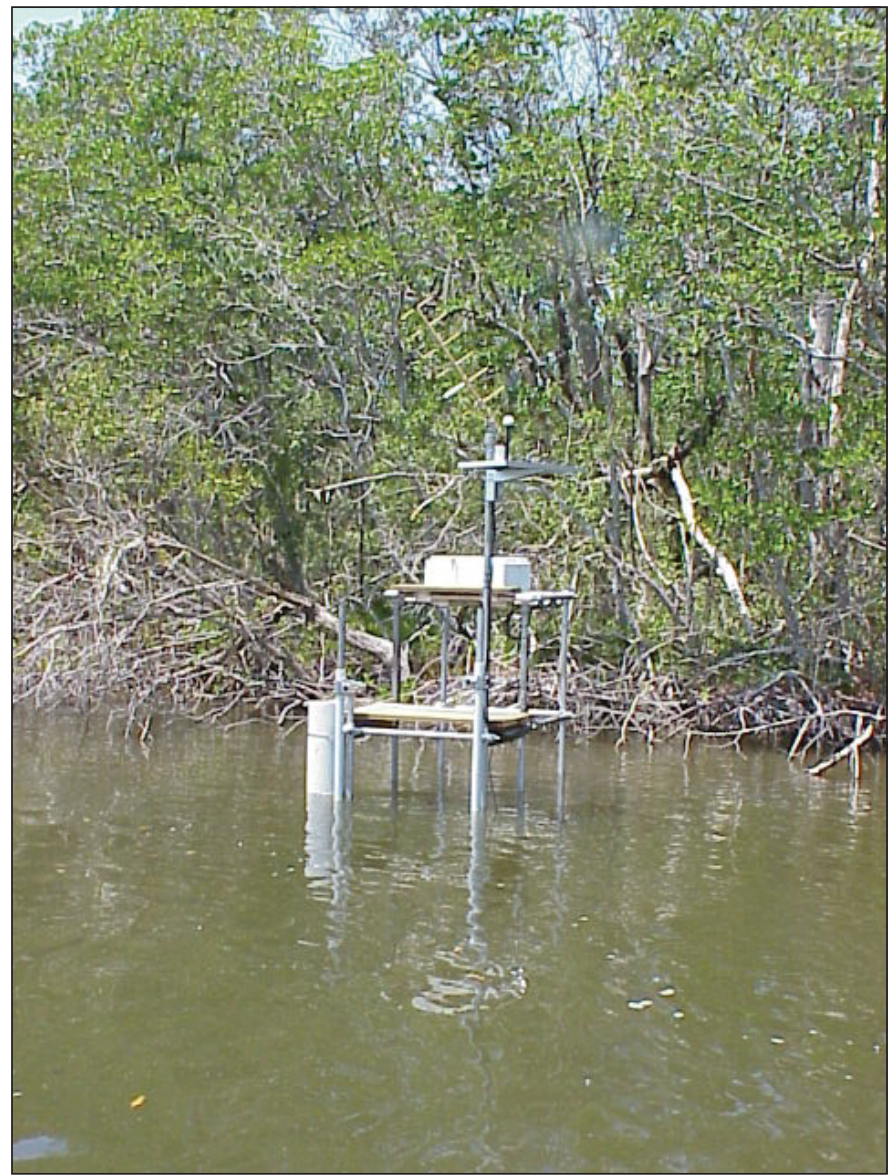

Figure 3. Streamflow and water-quality station at Faka Union River, May 2006.

discharge, using standard USGS methods (Levesque and Oberg, 2012). Data were tidally influenced at all sites, and therefore discharge data were filtered with the Godin lowpass filter to remove tidal frequencies according to USGS policy (Godin, 1972; U.S. Geological Survey, 2010). Positive discharge indicates flow to the Gulf of Mexico, and negative discharge indicates reverse flow. Mean daily values of filtered discharge for all sites can be accessed through the USGS NWISWeb (U.S. Geological Survey, 2015).

Near-surface and near-bottom salinity monitors were installed at several sites (fig. 2) to describe stratification. Nearsurface salinity monitors were installed in floating mounts, and recorded data at approximately $1 \mathrm{ft}$ below the water's surface. Near-surface salinity was discontinued at all sites in 2011 because of the observance of minimal stratification in the water column. Near-bottom salinity monitors were installed at depths ranging from 4 to $8 \mathrm{ft}$ below the water's surface. Waterquality monitoring data were computed using standard USGS methods (Wagner and others, 2006).
Rainfall data were obtained from the SFWMD DBHYDRO Web site (South Florida Water Management District, 2015c). Rainfall data presented herein are from the SFWMD station located at the Dan House Prairie (DANHP; fig. 1) within the Fakahatchee Strand Preserve Park. When data were missing from DANHP, rainfall was estimated based upon trends at nearby rainfall stations accessed from DBHYDRO, including Southern Golden Gate Estates weather station (SGGEWX), Fakahatchee Strand North Rainfall (FKSTRN), and Collier-Seminole State Park (COLLISEM) (fig. 1). Missing data in May and June 2007 at DANHP were estimated to be zero based on trends at the FKSTRN; SGGEWX and COLLISEM were not operational at that time. Missing data in May 2013 at DANHP were assumed to be zero, based on the three comparison sites. Data for December 2007, January 2008, and October 2013 were estimated based on the three comparison sites and available data from DANHP.

\section{Annual and Seasonal Rainfall}

The long-term (1981-2010) average rainfall for the area is 54.54 in. (South Florida Water Management District, 2015b). During 2007-14, the average rainfall in the study area was 49.44 in. The highest rainfall occurred in 2013, and the lowest rainfall was in 2011 (fig. 4). Wet season (June-October) rainfall totals ranged from 31.36 in. during 2008 to 44.93 in. during 2013. The average wet season rainfall was 36.37 in. during 2007-14. Dry season (November-May) rainfall totals ranged from $8.49 \mathrm{in}$. during 2011 to 21.11 in. during 2013 (table 2). The average dry season rainfall was 13.07 in. during 2007-14.

Tropical Storm (TS) Fay affected the area during the study period. TS Fay made its first Florida landfall at Key West shortly before 5:00 p.m. on Monday, August 18, 2008. TS Fay maintained strong tropical storm force strength, with winds up to 65 miles per hour, during the evening and overnight hours of August 18 as it approached the southwest Gulf Coast and made its first peninsular landfall at Cape Romano shortly before 5 a.m. on Tuesday, August 19. Rainfall from TS Fay substantially affected the area during the study period; however, the rainfall was variable throughout the study area. About 4.34 in. of rain were recorded at DANHP between August 18 and 25, and 2.15 in. were recorded on August 22. Between August 18 and 25, the FKSTRN station recorded 11.14 in. of rain, including 3.1 in. on August 18 and 3.95 in. on August 19. The SGGEWX station recorded 9.42 in. of rain during August 18-25, including 5.02 in. on August 19. The COLLISEM stations recorded 7.26 in. of rain during this period. 


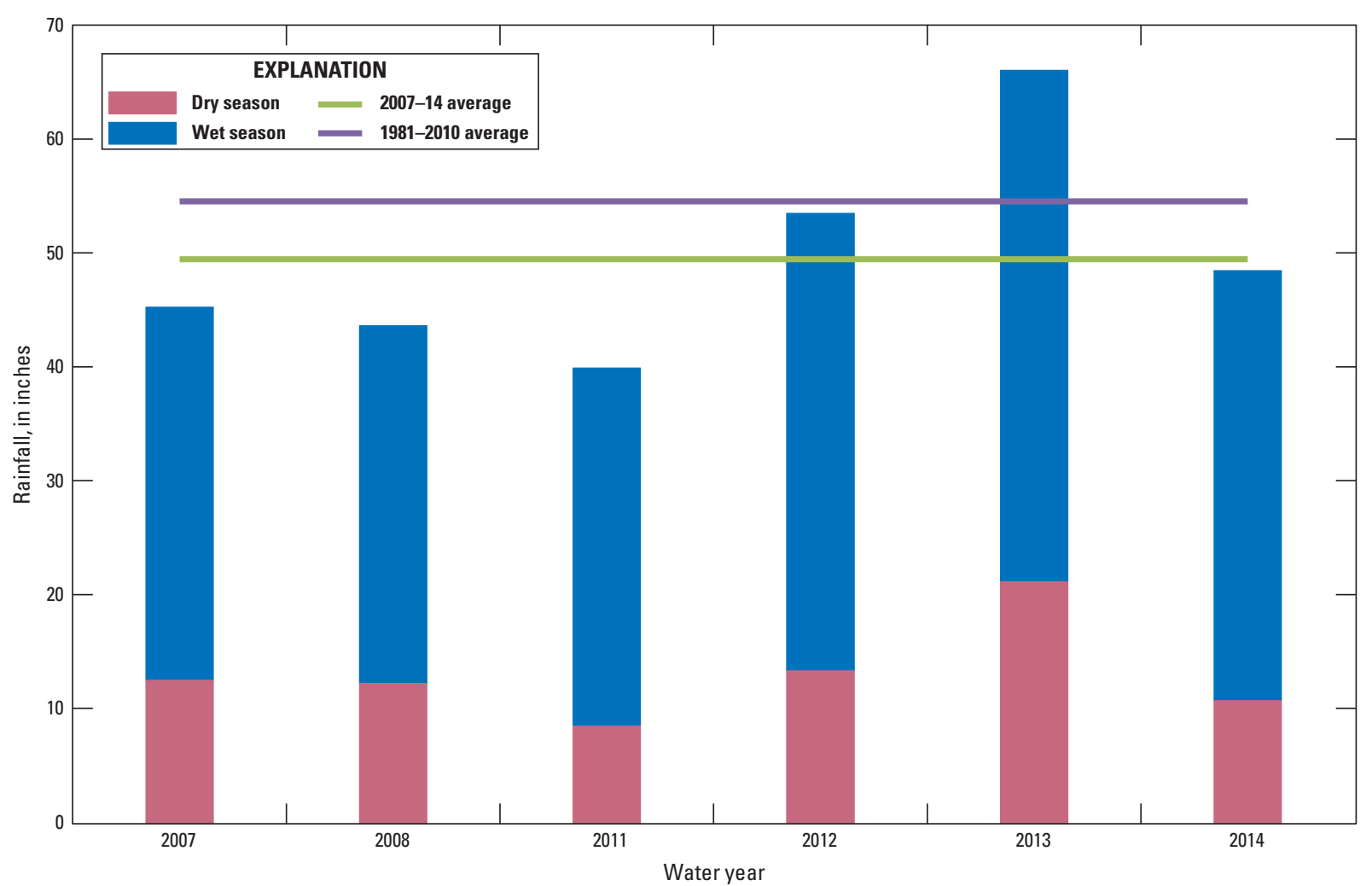

Figure 4. Annual, seasonal, and average rainfall in the northern Ten Thousand Islands, water years 2007-14, calculated using data obtained from South Florida Water Management District rainfall stations.

Table 2. Annual and seasonal rainfall totals in the northern Ten Thousand Islands, water years 2007-14.

[Rainfall totals were calculated from South Florida Water Management District (2015b) data and are reported in inches]

\begin{tabular}{cccc}
\hline Water year & Dry season & Wet season & Annual \\
\hline 2007 & 12.51 & 32.72 & 45.23 \\
2008 & 12.23 & 31.36 & 43.59 \\
2011 & 8.49 & 31.38 & 39.87 \\
2012 & 13.33 & 40.13 & 53.46 \\
2013 & 21.11 & 44.93 & 66.04 \\
2014 & 10.74 & 37.70 & 48.44 \\
\hline
\end{tabular}

\section{Annual and Seasonal Flow Characteristics of Tidal Rivers}

Annual and seasonal flow characteristics were determined for five tidal rivers. For the purpose of this report, the Faka Union River refers to the USGS discharge station, which measures flow from the Faka Union Canal and the Faka Union River. Faka Union River is the largest contributor of freshwater to the TTI estuary. Annual flow at Faka Union River was highest in 2013 (359,017 acre-feet) and lowest in 2014 (111,675 acre-feet) (fig. 5). Annual flow at East River was highest in 2014 (20,587 acre-feet) and lowest in 2011 (7,008 acre-feet) with no data recorded in water years 2012 and 2013. Annual flow at Little Wood River was highest in 2008 (21,749 acre-feet) and lowest in 2011 (4,408 acre-feet) with no data recorded in water years 2012-14. Annual flow at Pumpkin River was highest in 2013 (4,907 acre-feet) and lowest in 2011 (-201 acre-feet). Annual flow at Blackwater River was highest in 2013 (18,345 acre-feet) and lowest in 2011 ( $-11,962$ acre-feet) (fig. 6). Blackwater River is connected to Palm River via Mud Bay, and the circulation between the two rivers is not well understood; negative flow at Blackwater River may become positive flow at Palm River.

Comparison of flow volumes at East River, Faka Union River, Pumpkin River, and Blackwater River indicated that Faka Union River accounted for more than 80 percent of the flow monitored in the area (fig. 7). The amount of monitored flow at East River increased to 16 percent in 2014, compared to 7 percent in 2008 and 5 percent in 2011. Increases in flow volume to rivers west of Faka Union River were not observed during the study. In 2014 the amount of flow contributed by Faka Union River decreased. 


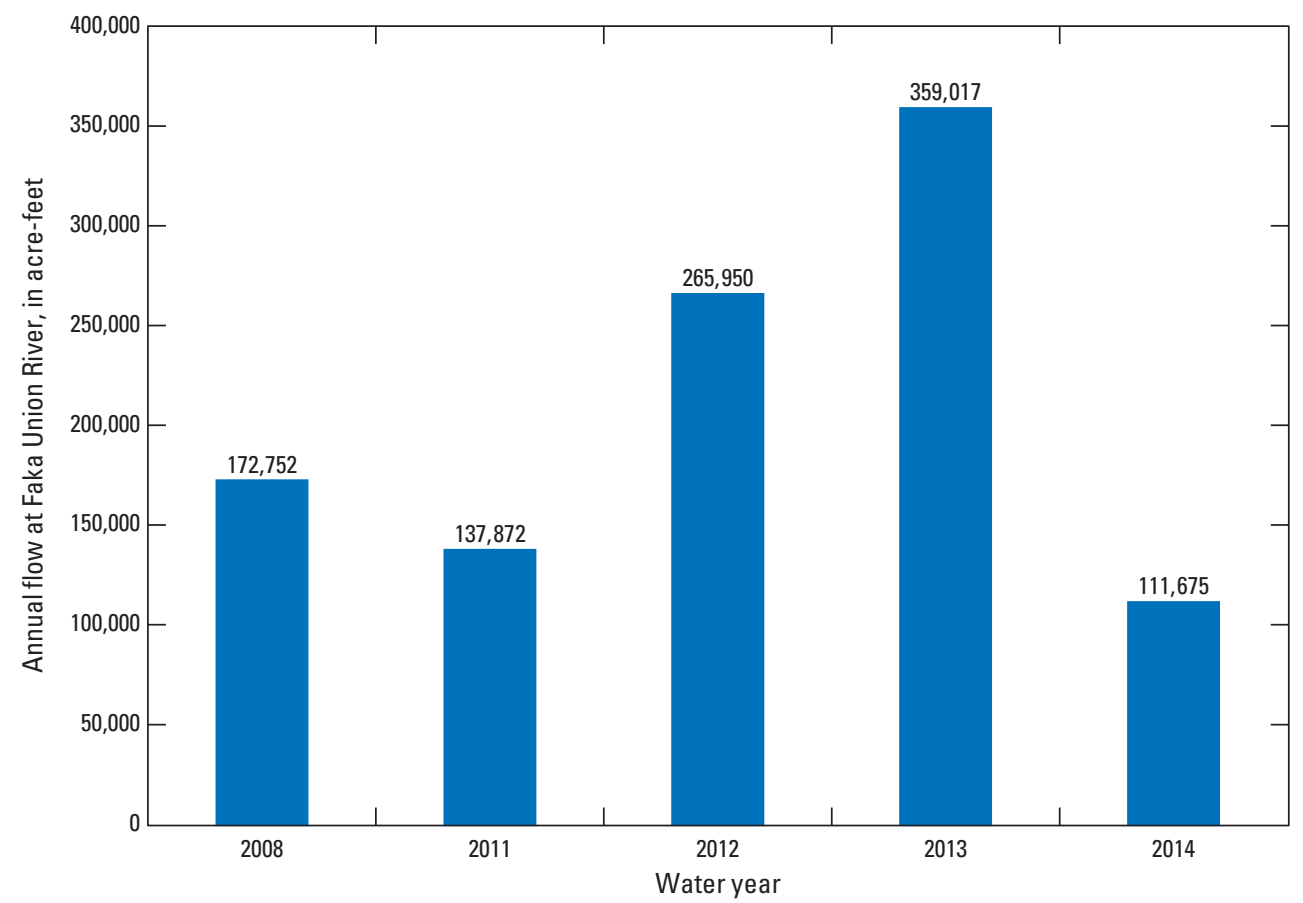

Figure 5. Annual flow at Faka Union River, water years 2008 and 2011-14.
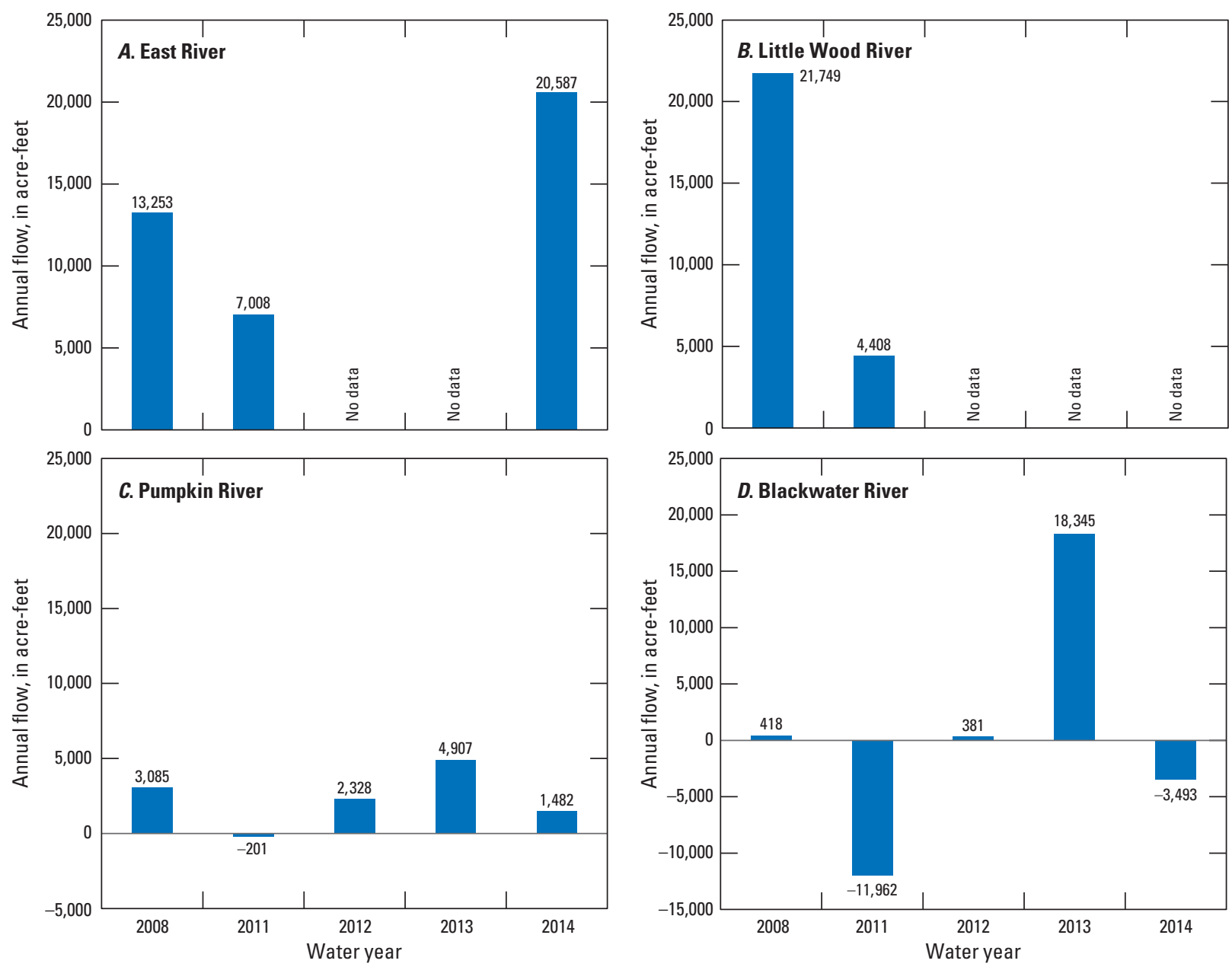

Figure 6. Annual flow at tidal tributaries, water years 2008 and 2011-14: $A$, East River; $B$, Little Wood River; C, Pumpkin River; and D, Blackwater River. 


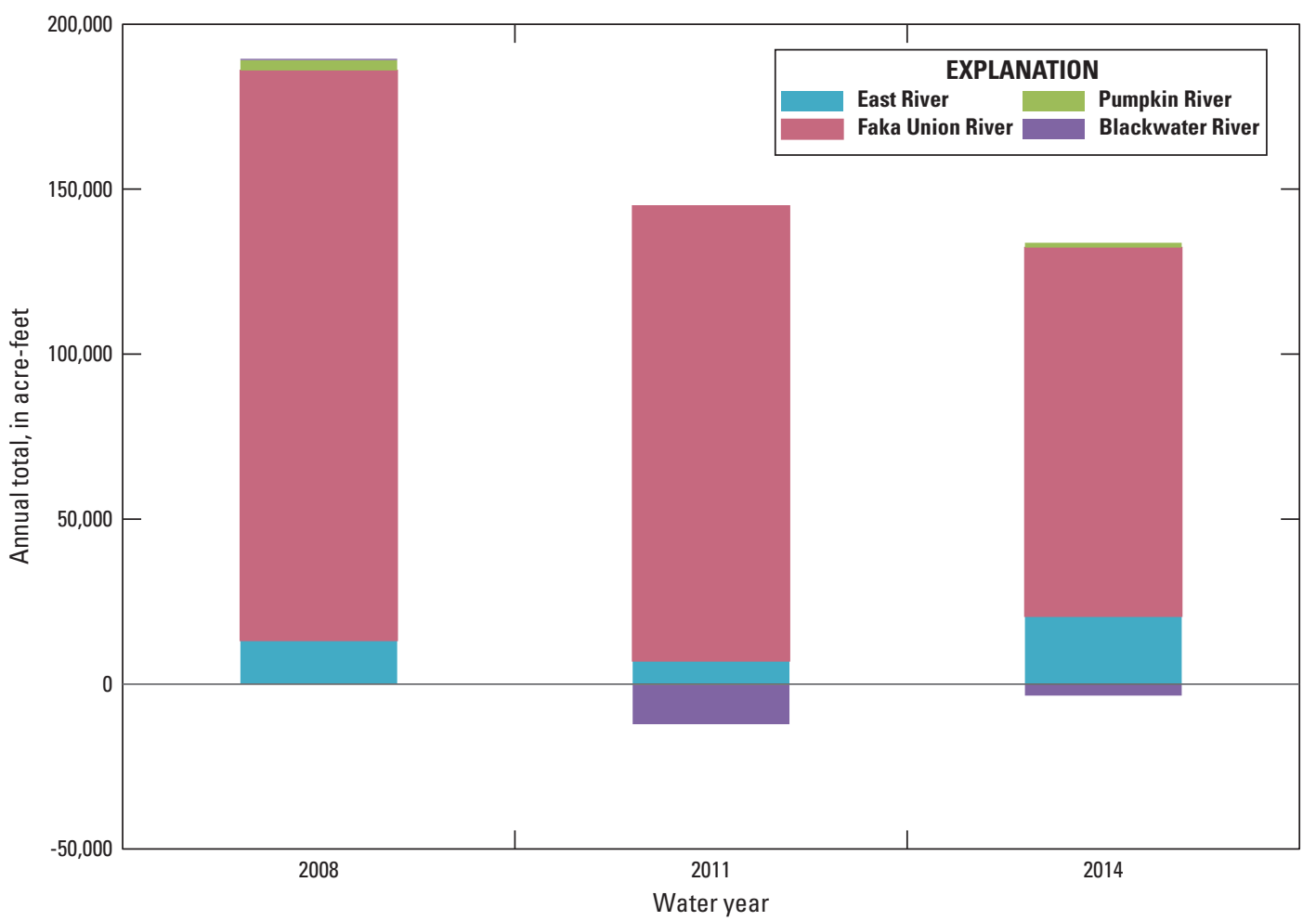

Figure 7. Flow contributed by East River, Faka Union River, Pumpkin River, and Blackwater River, water years 2008, 2011, and 2014.

Greater rainfall generally resulted in higher flow volumes (fig. 8), although there were several exceptions to this pattern. In 2008, Pumpkin River and Blackwater River had greater annual flow volumes per inch of rainfall than during any other year. Large spatial variations in rainfall from TS Fay may be responsible for these results, and the DANHP rainfall station may not have adequately represented the amount of rainfall that occurred to the west of Faka Union River. Faka Union River demonstrated the same trend during the study, with the exception of 2014. In 2014 the total annual flow in Faka Union River was less per inch of rainfall than in previous years, and this change is likely linked to restoration efforts, including the plugging of Prairie Canal. East River demonstrated higher flow with greater rainfall for the 3 years that had available data.

Distinct seasonal patterns occur in flow rates in the TTI estuary, and those patterns coincide with rainfall patterns. Wet season (June through October) flows are dominated by positive flows moving down the Faka Union River. During the dry season (November to May), flows at the Faka Union River can be negative, flowing up the river, even when the flows are positive at nearby rivers, potentially due to flow controlled by the weir. The weir at Faka Union Canal does not allow water to flow to the estuary until the water elevation exceeds the weir crest; Faka Union Canal is the only tributary controlled by a structure. Negative flows are likely due to water moving in with the tide and not flowing out towards the Gulf. During high tide, the water can breach the tributary banks and flood the tidal wetlands; when the tide recedes, some of the water remains in the tidal wetlands.

Wet season flow volumes ranged widely during the study, from a low of -989 acre-feet at Blackwater River in 2011 to a high of 257,956 acre-feet at Faka Union River in 2013 (fig. 9). Faka Union River was the dominant contributor of freshwater to the estuary in all water years. Excluding the Faka Union River, the largest contributors of monitored flow were Little Wood River in 2008, East River in 2011 and 2014, and Blackwater River in 2012 and 2013. No data were available for Little Wood River after 2011. Pumpkin River was the smallest contributor of flow in all water years. The highest wet season flows at Faka Union River, Pumpkin River, and Blackwater River occurred in 2013; no data were available for East River or Little Wood River during 2013. The lowest wet season flow for all sites occurred in 2011, and Blackwater River had a negative wet season flow volume in 2011.

Dry season flow volumes ranged from $-16,712$ acre-feet in 2008 to 118,866 acre-feet in 2012 at Faka Union River. Faka Union River was the greatest contributor of flow volume during the dry season in 2011, 2012, and 2013. In 2008, the Pumpkin River was the only station with positive net flow during the dry season, and East River had the greatest flow during the dry season in 2014. The highest flow during the dry season occurred in 2012. Blackwater River, Little Wood River, and East River all had net negative flow volumes during the dry season, with the exception of East River in 2014 (fig. 10). 

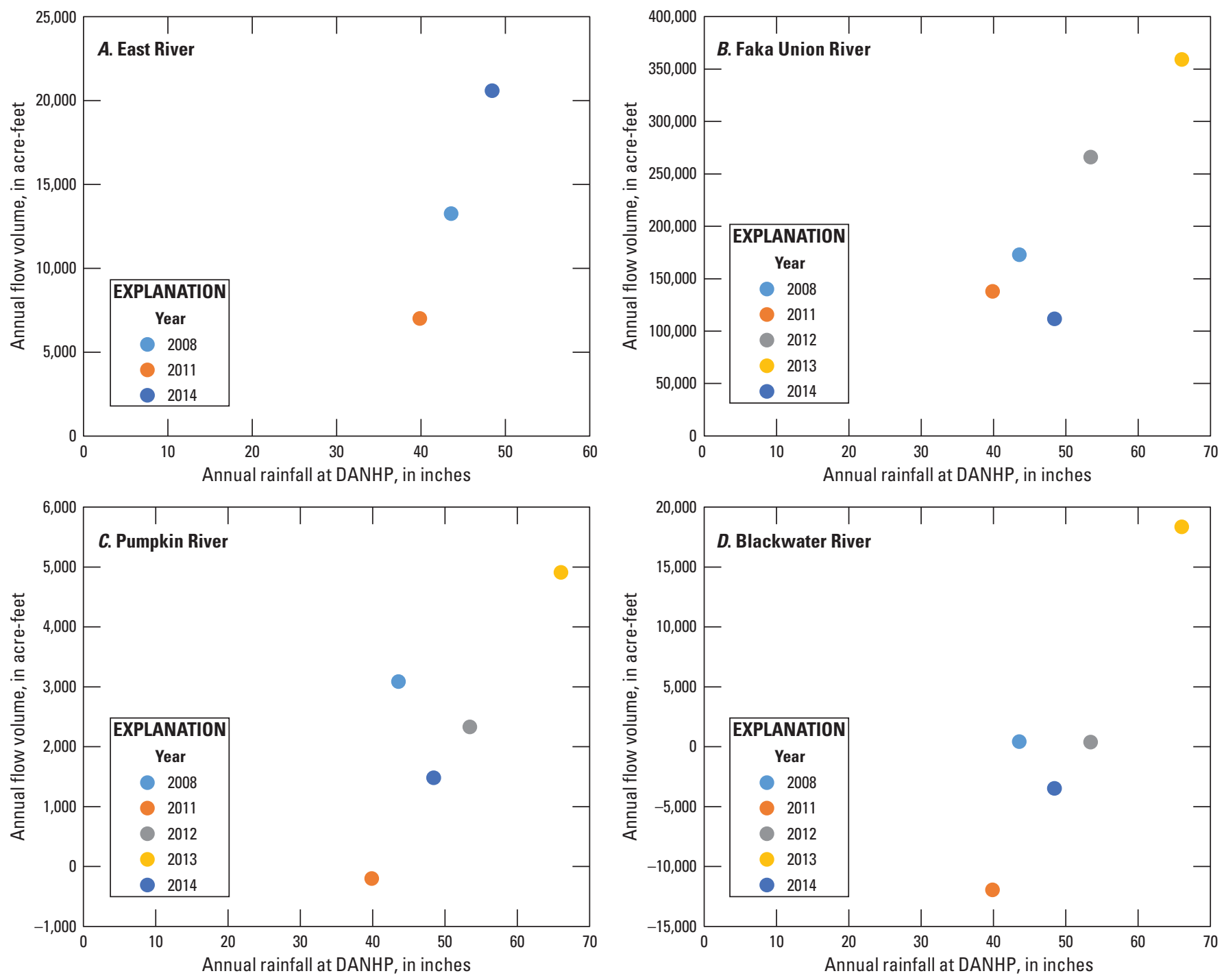

Figure 8. Annual flow volume compared to rainfall by water year: $A$, East River; $B$, Faka Union River; $C$, Pumpkin River; and $D$, Blackwater River. [DANHP, Dan House Prairie rainfall station. Note that the $y$-axes scales differ for each station] 

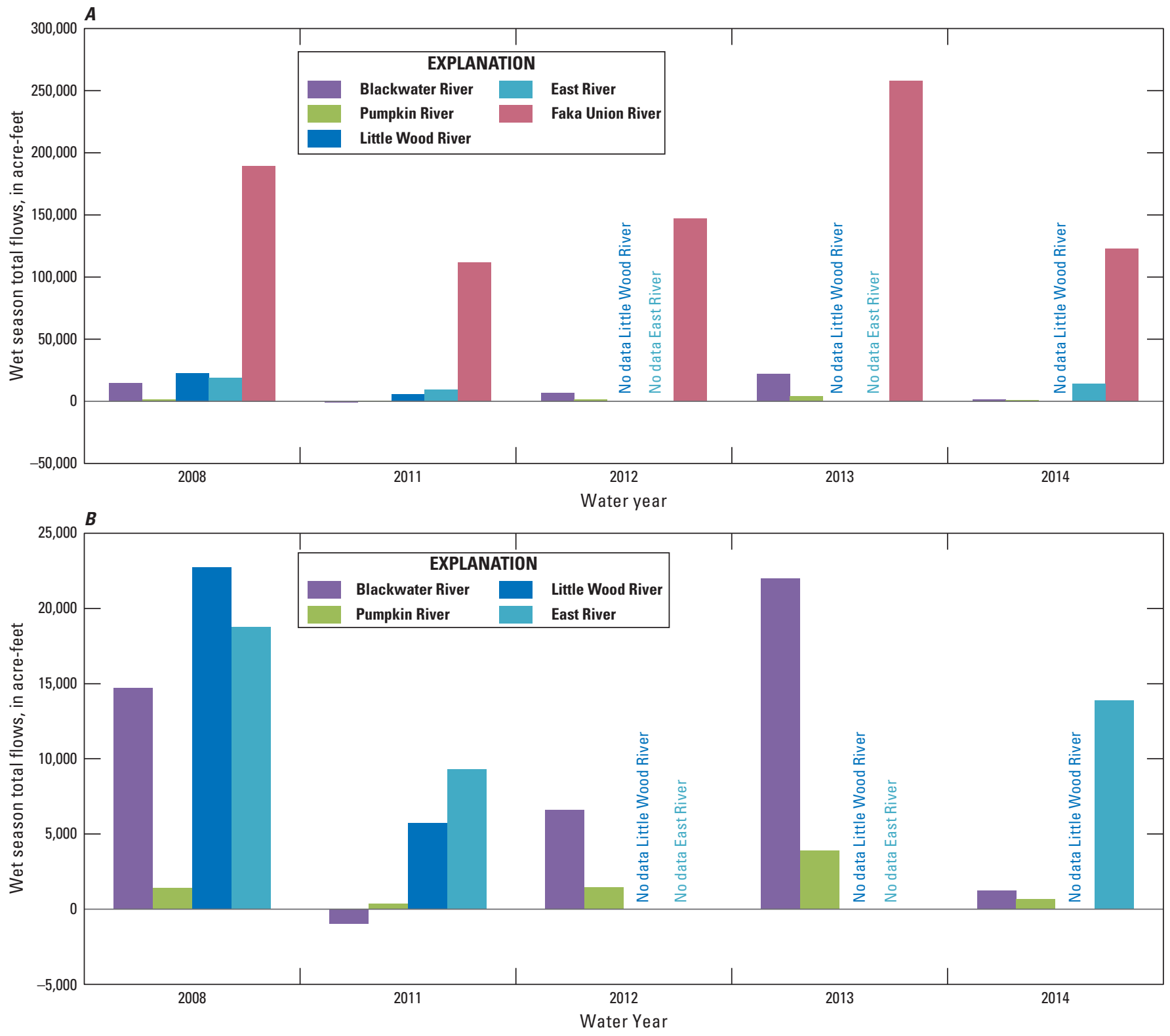

Figure 9. Wet season total flows, water years 2008 and $2011-14$, $A$, including and $B$, excluding the Faka Union River. 

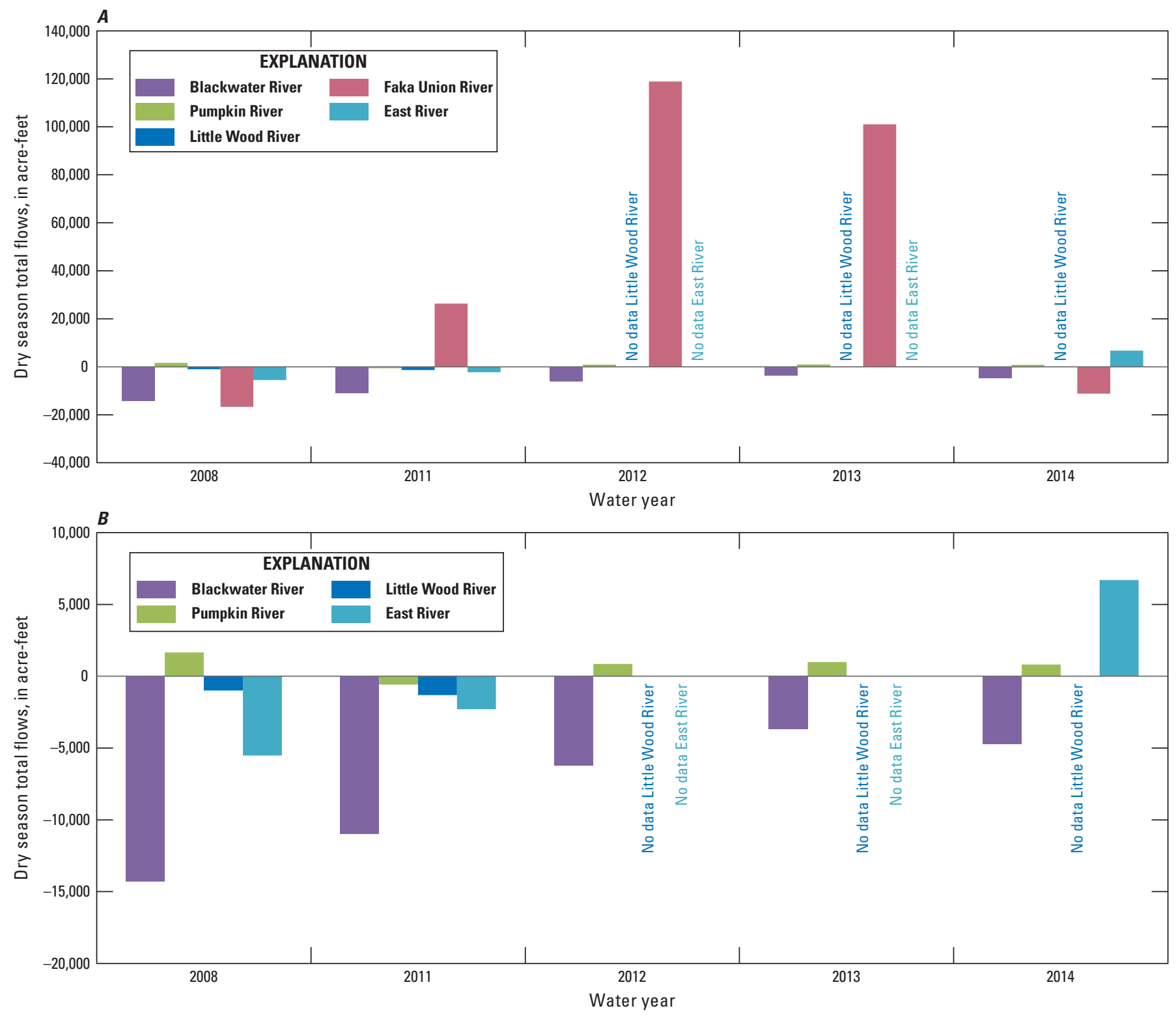

Figure 10. Dry season total flows, water years 2008 and 2011-14, $A$, including and $B$, excluding the Faka Union River.

Faka Union River contributed 84 to 94 percent of the monitored flow volume during the wet season. Pumpkin River contributed up to 1 percent, Blackwater River contributed up to 7 percent, and East River contributed up to 8 percent of the monitored flow. During the dry season, Faka Union River contributed all of the flow during 2011 and contributed no positive flow during 2008 or 2014. The percentage of positive flow during the dry season increased in 2014 for East River. East River had negative flow in 2008 and 2011 during the dry season and was the largest contributor to dry season flow volume during 2014.

The highest monthly total flows occurred in September 2008 for Blackwater River (7,187 acre-feet), Little Wood River (11,702 acre-feet), Faka Union River (83,338 acre-feet), and East River (10,573 acre-feet) (fig. 11). The high monthly flows can be attributed to the large amount of rainfall from TS Fay in late August 2008. The highest monthly total flow at Pumpkin River occurred in July 2013 (1,332 acre-feet) (fig. 11), corresponding with the highest wet season rainfall recorded during the study.
The lowest monthly total flows occurred at or near the end of the dry season, with the exception of Pumpkin River. The lowest monthly total flows occurred at Blackwater River $(-2,498$ acre-feet) and East River (-1,514 acre-feet) in May 2008 (fig. 11). The lowest monthly total flow at Little Wood River (1,847 acre-feet) occurred in April 2007. The lowest monthly total flow at Pumpkin River ( -461 acre-feet) occurred in October 2011. The lowest monthly total at Faka Union River was $-7,857$ acre-feet in May 2007 (fig. 11).

Blackwater River had the highest percentage of time with negative flows (table 3). Total monthly flows at Blackwater River were negative 7 to 10 months a year during 2008 and 2011-14. The only stations with no monthly net negative flows in any year during the study period were Pumpkin River in 2012 and Faka Union River in 2011-13. In 2014, East River had 1 month of net negative flow compared to 6 months in 2011 and 7 months in 2008 . 

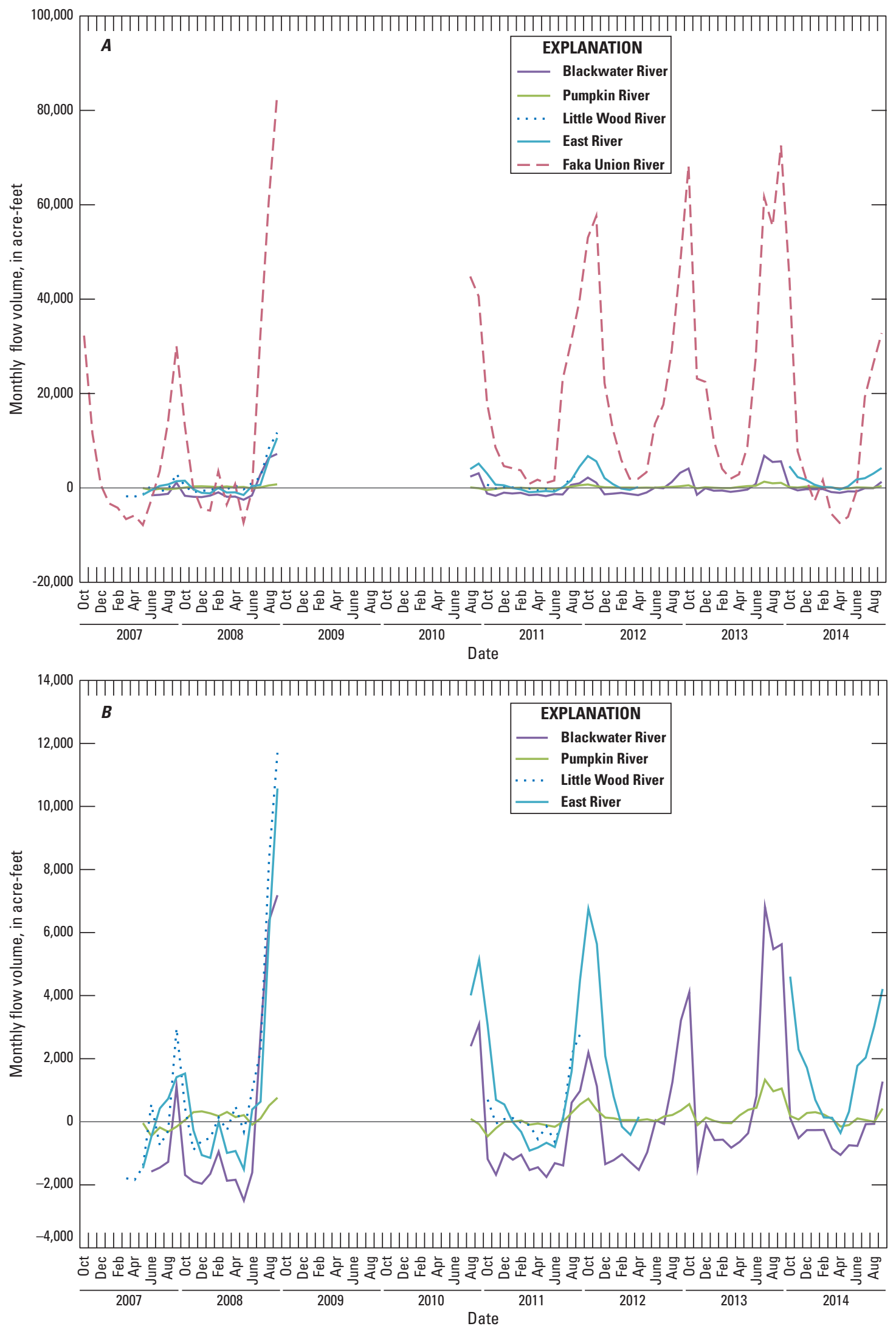

Figure 11. A, Monthly flow volume at Faka Union River, East River, Little Wood River, Pumpkin River, and Blackwater River, water years 2007-14. B, Monthly flow volume at East River, Little Wood River, Pumpkin River, and Blackwater River, water years 2007-14. 
Table 3. Percentage of total monthly flow that was negative during water years 2008 and 2011-14 in the northern Ten Thousand Islands estuary.

[All values are percentages; - , no data collected during this period]

\begin{tabular}{cccccc}
\hline $\begin{array}{c}\text { Water } \\
\text { year }\end{array}$ & $\begin{array}{c}\text { Blackwater } \\
\text { River }\end{array}$ & $\begin{array}{c}\text { Little } \\
\text { Wood } \\
\text { River }\end{array}$ & $\begin{array}{c}\text { Pumpkin } \\
\text { River }\end{array}$ & $\begin{array}{c}\text { Faka } \\
\text { Union } \\
\text { River }\end{array}$ & $\begin{array}{c}\text { East } \\
\text { River }\end{array}$ \\
\hline 2008 & 75 & 42 & 8 & 50 & 58 \\
2011 & 83 & 50 & 50 & 0 & 50 \\
2012 & 58 & - & 0 & 0 & - \\
2013 & 58 & - & 25 & 0 & - \\
2014 & 83 & - & 25 & 42 & 8 \\
\hline
\end{tabular}

\section{Salinity Patterns of Tidal Rivers and Bays}

The highest annual mean salinity recorded was $34.0 \mathrm{ppt}$ at Faka Union Boundary in 2011 (fig. 12G, table 4). This finding is to be expected due to the proximity of the Faka Union Boundary to the Gulf of Mexico. The highest annual mean salinities at Pumpkin River (33.7 ppt), Little Wood and Blackwater Rivers (31.6 ppt), East River (27.9 ppt), and Faka Union River (27.3 ppt) were all in 2011. The highest annual mean salinity for Palm River (30.4 ppt) was in 2014, but no salinity data were available in 2011. The lowest annual mean salinity (18.8 ppt) was recorded in 2013 at Faka Union River and East River. The lowest annual mean salinities at Blackwater River (23.8 ppt), Pumpkin River (26.8 ppt), and Palm River (25.2 ppt) were all in 2013. The lowest annual mean salinities at Little Wood River (29.0 ppt) and the Faka Union Boundary (33.3 ppt) were in 2008 (fig. 13). No data were available for Faka Union Boundary and Little Wood River in 2013.

The instantaneous salinity values varied widely during this study (fig. 12, table 4). At East River, the highest instantaneous salinity was $41.2 \mathrm{ppt}$ on May 19, 2013, and the lowest was $0.8 \mathrm{ppt}$ on September 28 and 29, 2013. The highest instantaneous salinity recorded at Little Wood River was $42.2 \mathrm{ppt}$ on May 26, 2008, and the lowest was 3.1 ppt on September 24, 2008. The highest instantaneous salinity value recorded at Pumpkin River was 43.4 ppt on May 26 and 27, 2008, and the lowest was $3.1 \mathrm{ppt}$ on October 10, 2012. The highest instantaneous salinity value recorded at Blackwater River was $42.1 \mathrm{ppt}$ on May 28, 2008, and the lowest was 0.7 ppt on September 24 and 25,2008 . The highest instantaneous salinity recorded at Palm River was 40.1 ppt on May 19, 2013, and the lowest was 3.4 ppt on October 8 and 9, 2012, and September 10 and 11,2013 . The highest instantaneous salinity value at Faka Union River was 41.4 ppt on May 28, 2008, and the lowest was $0.2 \mathrm{ppt}$ on numerous days in September 2006. The highest instantaneous salinity at Faka Union Boundary was $41.2 \mathrm{ppt}$ on May 17, 2008. The lowest instantaneous value was $12.2 \mathrm{ppt}$ on September 27, 2008.

The highest percentage of salinities less than $35 \mathrm{ppt}$ (full seawater) occurred during 2013 (fig. 13 and table 5), corresponding with the highest rainfall totals. The proportion of salinity values at Pumpkin River greater than or equal to 35 ppt was 57.0 percent in 2011, followed by 48.3 percent in 2008, 34.9 percent in 2014, 29.3 percent in 2012, and 25.7 percent in 2013. More than half of the values recorded (51.1 percent) were greater than or equal to $35 \mathrm{ppt}$ at the Faka Union Boundary in 2008, compared to 30.7 percent in 2011. Both 2008 and 2011 have missing data during the dry season at the Faka Union Boundary, therefore the percentage of salinity values greater than $35 \mathrm{ppt}$ would be expected to be higher than reported. The proportion of salinity values at Blackwater River greater than or equal to $35 \mathrm{ppt}$ was 50.7 percent in 2011, followed by 47.4 percent in 2008, 39.5 percent in 2014, 34.6 percent in 2012, and 28.4 percent in 2013. At Little Wood River, salinity values were greater than or equal to 35 ppt 39.9 percent of the time in 2008 and 26.0 percent of the time in 2011. The proportion of salinity values at Palm River greater than or equal to $35 \mathrm{ppt}$ was 36.1 percent in 2012 , followed by 35.8 percent in 2014 and 26.3 percent in 2013. The proportion of salinity values at Faka Union River greater than or equal to $35 \mathrm{ppt}$ was 29.6 percent in 2008 , followed by 28.4 percent in $2011,20.3$ percent in $2014,19.7$ percent in 2012, 18.4 percent in 2007, and 11.1 percent in 2013. The proportion of salinity values at East River greater than or equal to 35 ppt was 29.0 percent in 2011, followed by 23.7 percent in $2008,16.4$ percent in $2014,8.1$ percent in 2012 , and 7.8 percent in 2013.

The relation between annual rainfall and salinity was similar at all sites (fig. 14); as annual rainfall increased, annual mean salinity decreased. Annual rainfall accounted for 89 to 94 percent of the variance in annual mean salinity. The slope of the regression line ranged from -0.25 for Pumpkin River to -0.32 for East River. There were no quantifiable changes in salinity and rainfall patterns between 2008 and 2014 that were attributable to restoration efforts. In 2008, all sites had a lower average salinity with a smaller amount of rainfall; this pattern is likely a result of the difficulty of accurately representing the rainfall associated with TS Fay. Rainfall stations had a wide range of rainfall totals during the storm, and the DANHP rainfall station may not have adequately represented the amount of rainfall. 

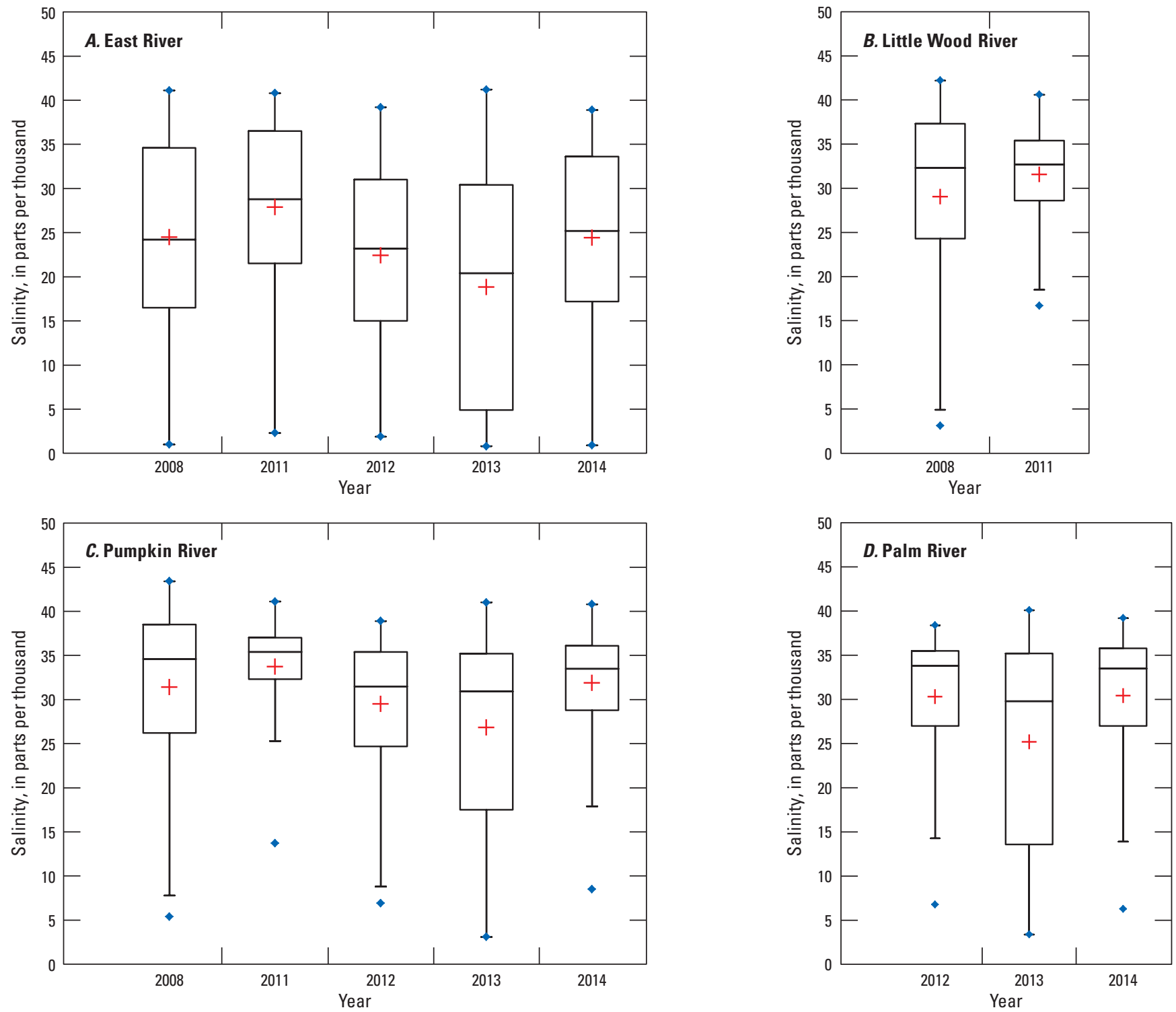

EXPLANATION

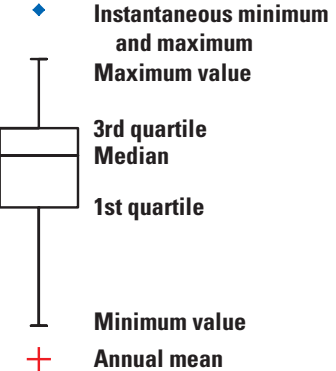

Figure 12. Salinity data by site and water year: $A$, East River; $B$, Little Wood River; $C$, Pumpkin River; $D$, Palm River; E, Blackwater River; F, Faka Union River; and G, Faka Union Boundary. 


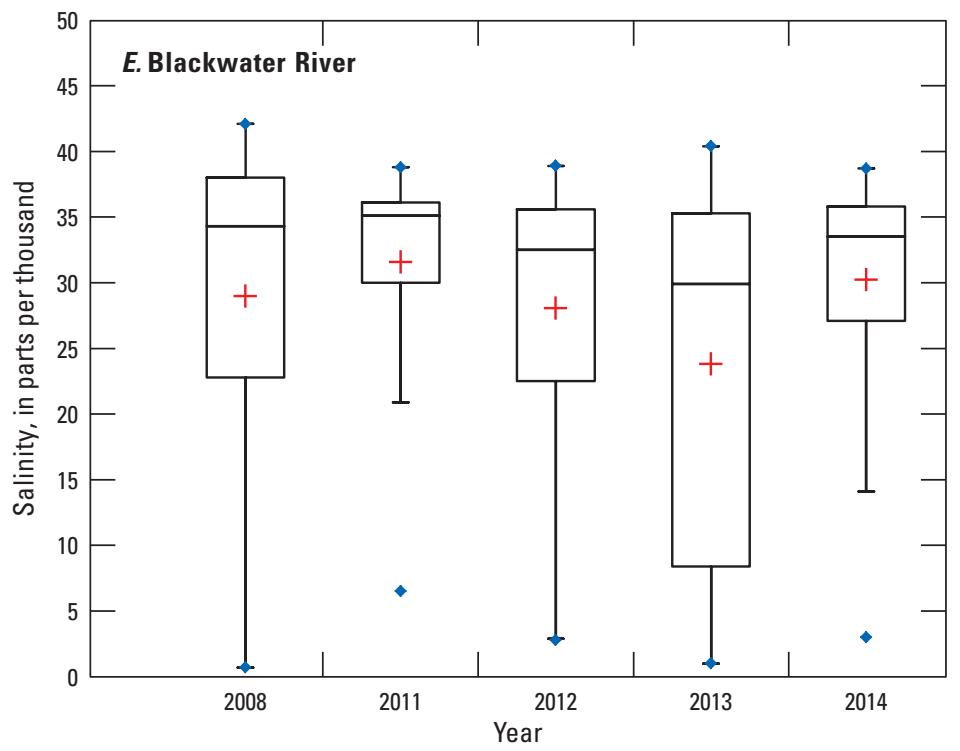

EXPLANATION

- Instantaneous minimum

and maximum

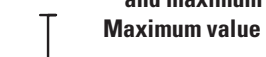

3rd quartile

Median

Minimum value

$+\quad$ Annual mean
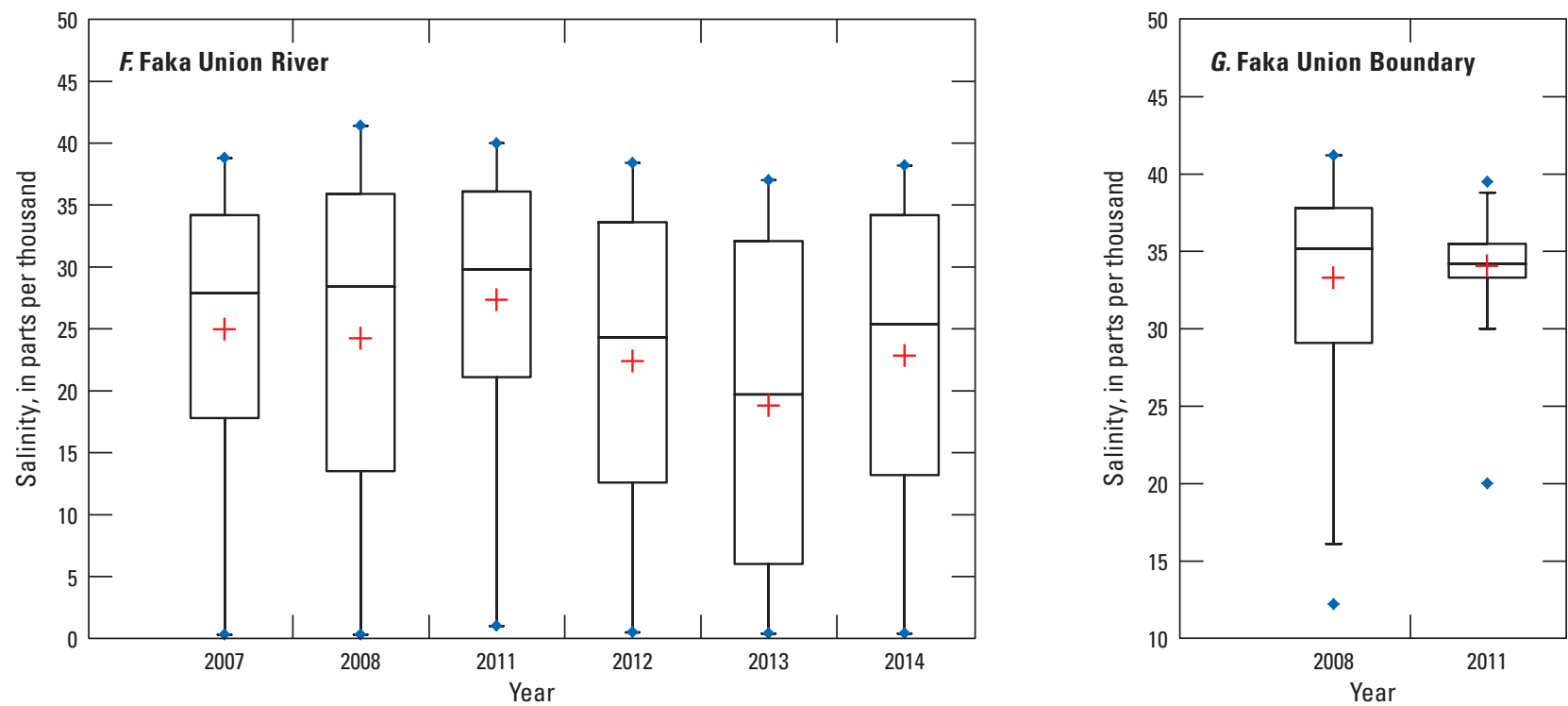

Figure 12. Salinity data by site and water year: $A$, East River; $B$, Little Wood River; $C$, Pumpkin River; $D$, Palm River; E, Blackwater River; F, Faka Union River; and G, Faka Union Boundary.-Continued 
Table 4. Annual mean and instantaneous minimum and maximum salinity values, water years 2007-14, in the northern Ten Thousand Islands estuary.

[-, incomplete water year, statistic not available; All salinity data are in parts per thousand]

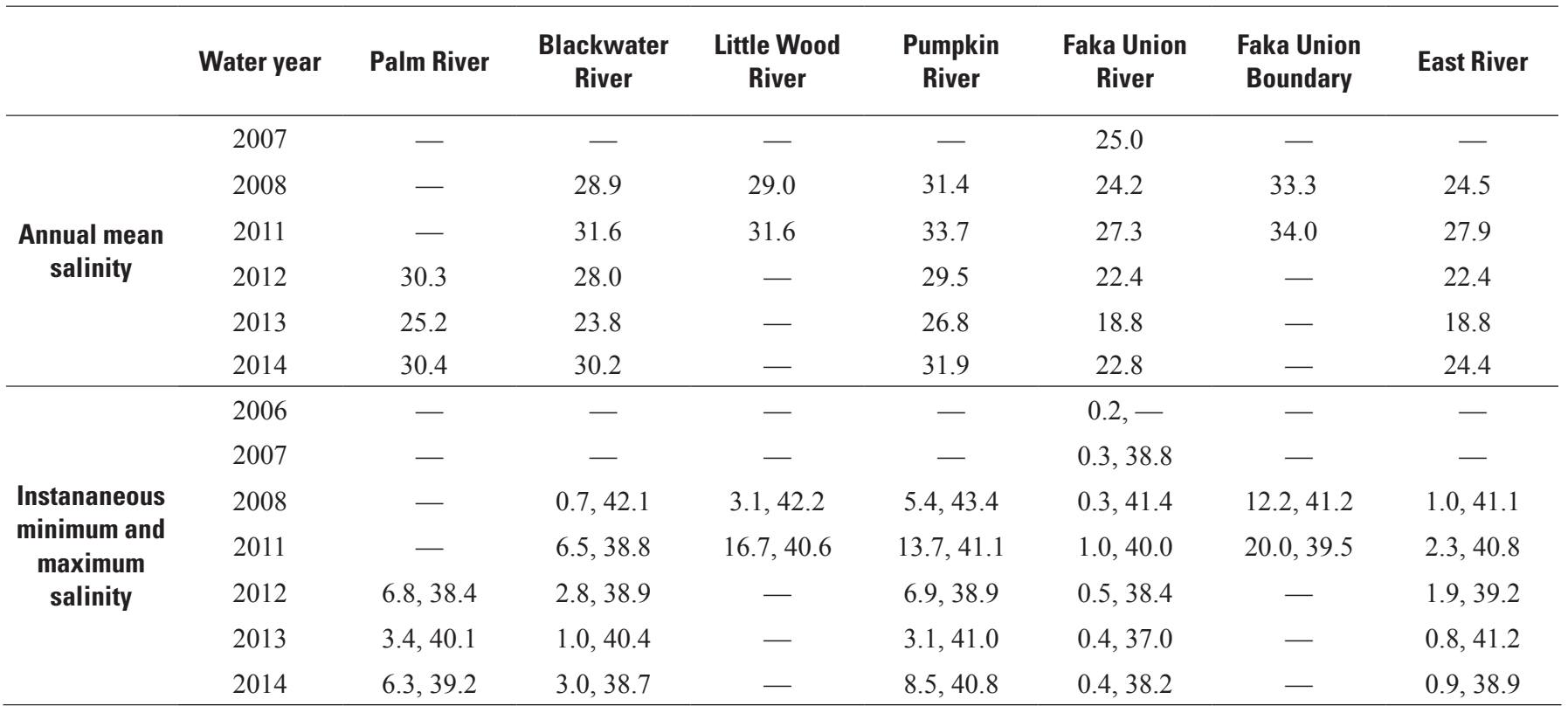

Table 5. Percentage of instantaneous salinity values greater than or equal to 35.0 parts per thousand, water years 2007-14, in the northern Ten Thousand Islands estuary.

[All values are percentages; - , no data collected during this period]

\begin{tabular}{|c|c|c|c|c|c|c|c|}
\hline Water year & Palm River & $\begin{array}{c}\text { Blackwater } \\
\text { River }\end{array}$ & $\begin{array}{l}\text { Little Wood } \\
\text { River }\end{array}$ & $\begin{array}{c}\text { Pumpkin } \\
\text { River }\end{array}$ & $\begin{array}{c}\text { Faka Union } \\
\text { River }\end{array}$ & $\begin{array}{l}\text { Faka Union } \\
\text { Boundary }\end{array}$ & $\begin{array}{l}\text { East } \\
\text { River }\end{array}$ \\
\hline 2007 & - & - & - & - & 18.4 & - & - \\
\hline 2011 & - & 50.7 & 26.0 & 57.0 & 28.4 & 30.7 & 29.0 \\
\hline 2012 & 36.1 & 34.6 & - & 29.3 & 19.7 & - & 8.1 \\
\hline 2014 & 35.8 & 39.5 & - & 34.9 & 20.3 & - & 16.4 \\
\hline
\end{tabular}



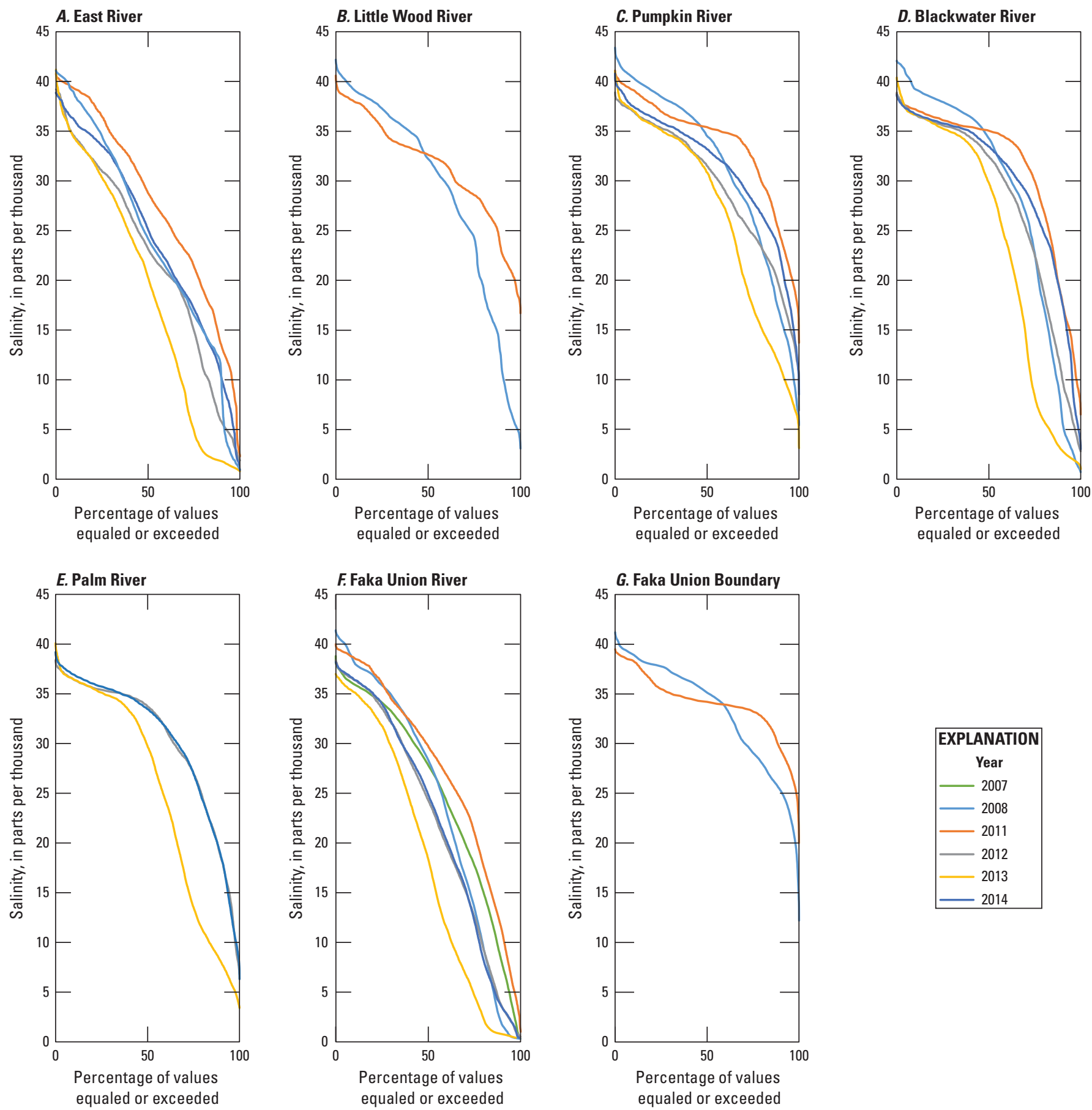

Figure 13. Salinity duration curves by site and water year: $A$, East River; $B$, Little Wood River; $C$, Pumpkin River; $D$, Blackwater River; E, Palm River; F, Faka Union River; and G, Faka Union Boundary. 

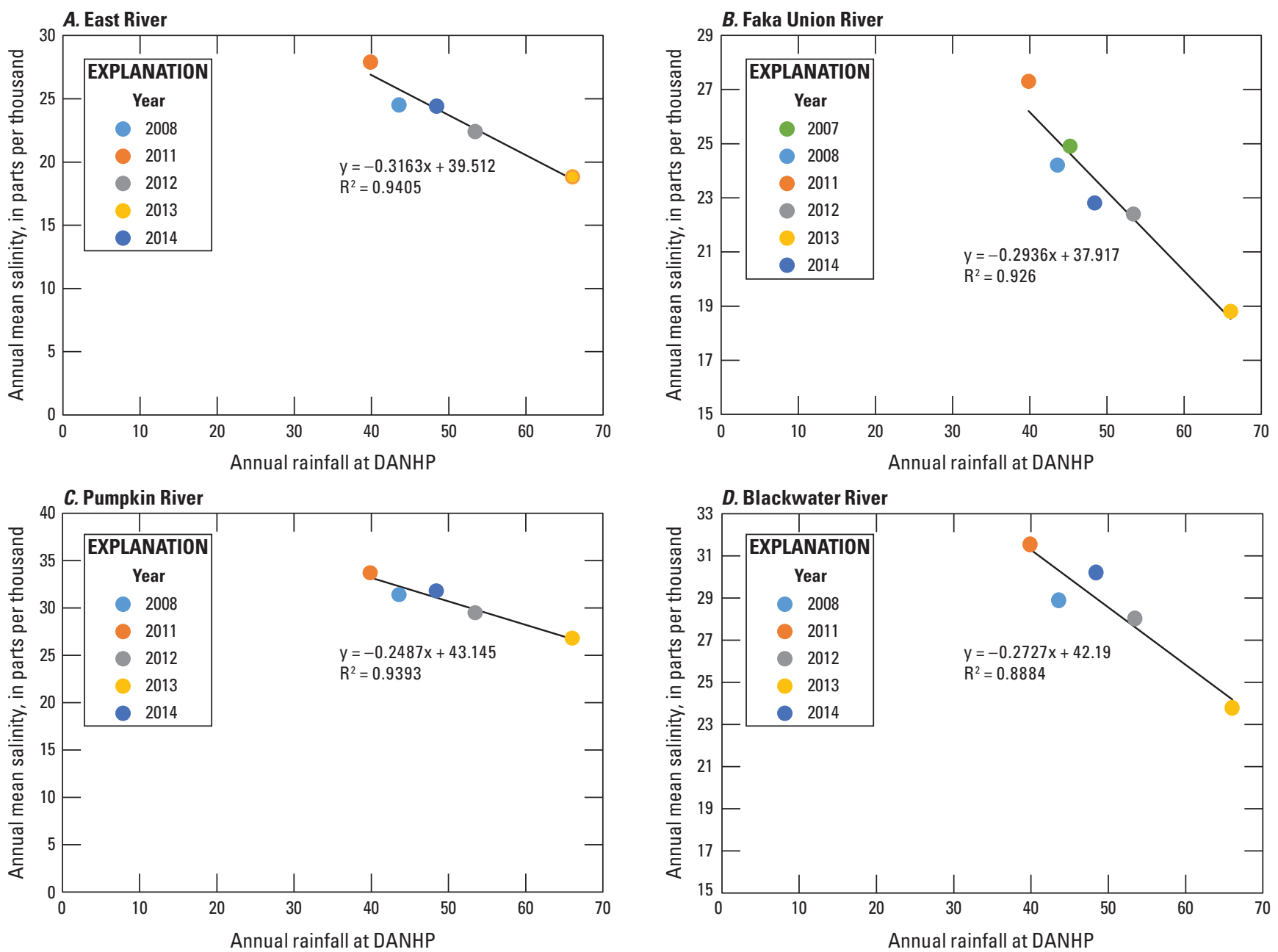

Figure 14. Relation between annual mean salinity and annual rainfall: $A$, East River; $B$, Faka Union River; $C$, Pumpkin River; and $D$, Blackwater River. [Years are water years. DANHP, Dan House Prairie rainfall station. Note that the $y$-axes scales differ for each station]

The lowest monthly mean salinities occurred at Faka Union River and East River (fig. 15, table 6), indicating they received a greater amount of freshwater than the other sites. Additionally, salinities began to decrease at Faka Union River and East River before the sites west of Faka Union River, indicating freshwater is received at Faka Union and East Rivers first. Monthly mean salinities varied by 15 to 38 ppt during the study at individual sites. The minimum monthly mean salinity at East River was 2.3 ppt in September 2013, and the maximum was $39.7 \mathrm{ppt}$ in May 2011. The minimum monthly mean salinity at Little Wood River was 7.9 ppt in September 2008, and the maximum was $39.8 \mathrm{ppt}$ in May 2008. The minimum monthly mean salinity at Pumpkin River was $11.5 \mathrm{ppt}$ in September 2013, and the maximum was 40.5 ppt in May 2008.
The minimum monthly mean salinity at Blackwater River was $5.1 \mathrm{ppt}$ in September 2013, and the maximum was $40.9 \mathrm{ppt}$ in May 2008. The minimum monthly mean salinity at Palm River was 9.0 ppt in September 2013, and the maximum was $37.4 \mathrm{ppt}$ in May 2014. The minimum monthly mean salinity at Faka Union River was 0.8 ppt in September 2006, and the maximum was $39.0 \mathrm{ppt}$ in May 2008. The minimum monthly mean salinity at Faka Union Boundary was $24.1 \mathrm{ppt}$ in September 2008, and the maximum was 39.2 ppt in May 2008. Faka Union Boundary had the smallest range in monthly mean salinity (15.1 ppt). Faka Union Boundary is located closest to the Gulf of Mexico and would be expected to have a small range in salinity values. 
Table 6. Maximum and minimum monthly mean salinity values, water years 2007-14, in the northern Ten Thousand Islands estuary. [-, incomplete water year, statistic not available; All salinity data are in parts per thousand]

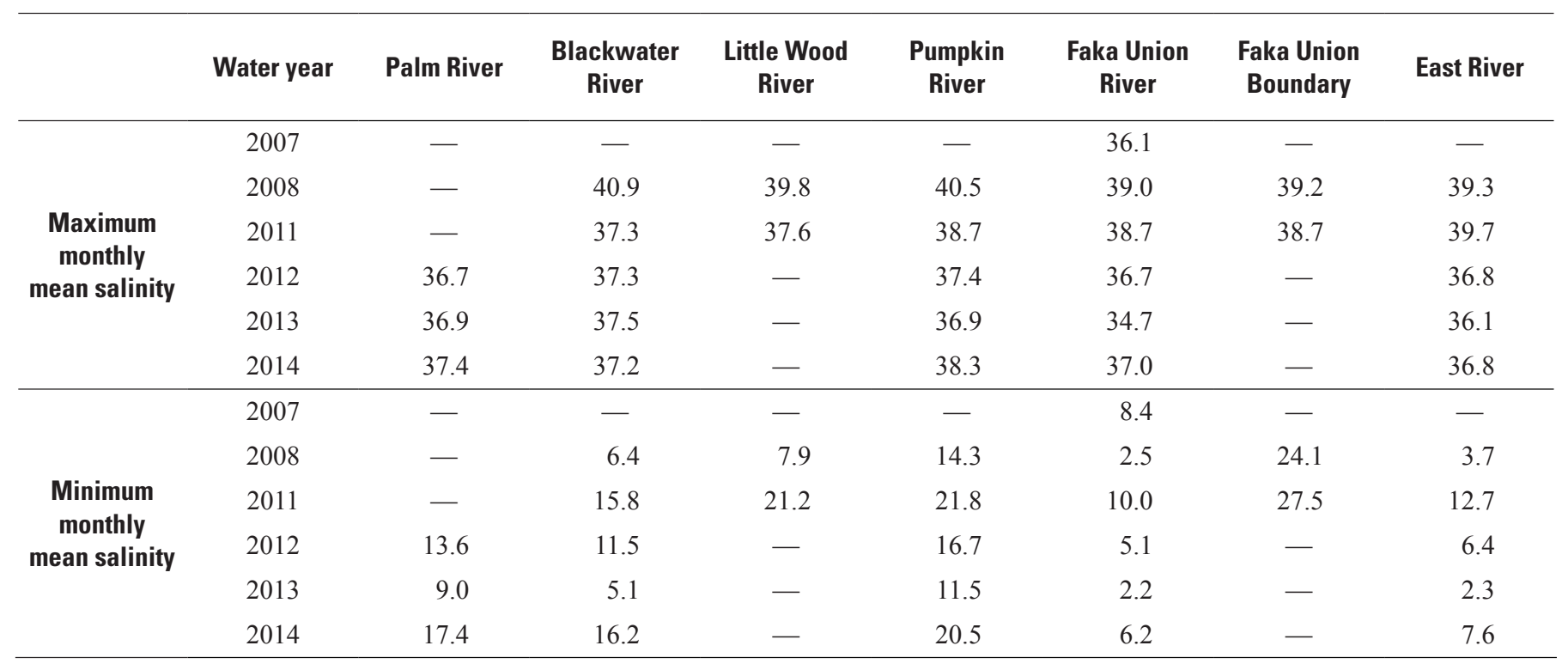

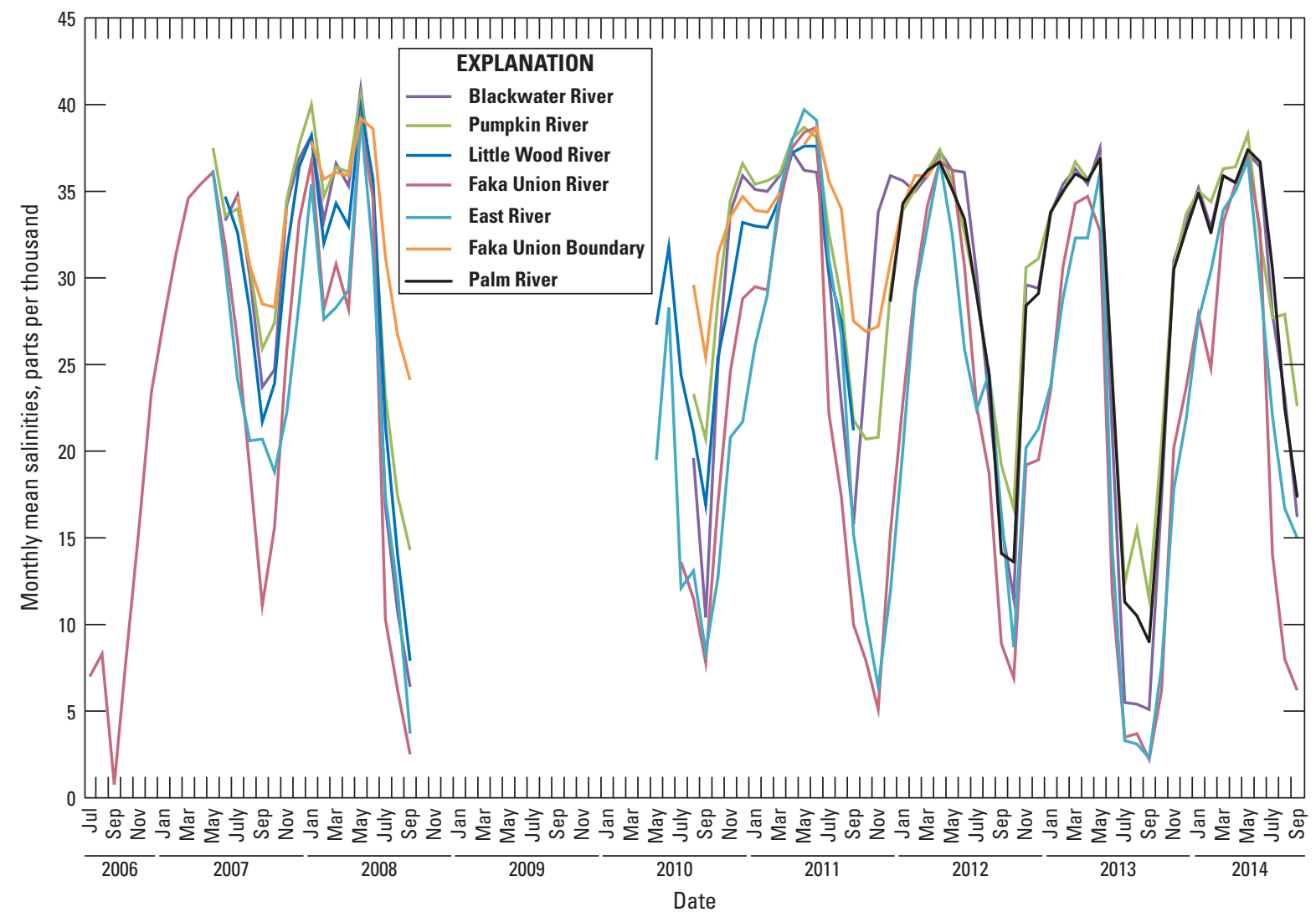

Figure 15. Monthly mean salinity values by site, July 2006 to September 2014, Ten Thousand Islands estuary area. 


\section{Summary}

Freshwater flow to the Ten Thousand Islands estuary has been altered by the construction of the Tamiami Trail and construction of features in the now-defunct Southern Golden Gate Estates. The Picayune Strand Restoration Project was implemented to improve freshwater delivery to the Ten Thousand Islands estuary. This report describes tributary flow and salinity patterns during preliminary restoration efforts and prior to the installation of pump stations as part of the Picayune Strand Restoration Project, providing baseline data for analyses of changes attributable to restoration efforts.

The USGS station named Faka Union River, which includes flow from the Faka Union Canal and the Faka Union River, was the dominant contributor of freshwater to the Ten Thousand Islands estuary, and supplied more than 80 percent of the monitored annual flow during 2008-14. Little Wood and East Rivers were the next largest contributors of annual flow. Pumpkin and Blackwater Rivers were the least substantial contributors of flow during most of the study period; however, Blackwater River was a substantial contributor of flow in 2013. In 2014, the percentage of monitored annual flow supplied by East River was more than doubled compared to 2008 and 2011. The increase in flow may be attributable to restoration efforts. There were no quantifiable changes in flow volume patterns west of the Faka Union River.

The lowest flow volumes at all sites occurred in 2011, corresponding with the lowest annual rainfall during the study. The highest annual flow volumes occurred in 2013 for Faka Union, Pumpkin, and Blackwater Rivers, corresponding with the highest annual rainfall; however, no streamflow data were available from Little Wood River and East River in 2013. Greater rainfall generally resulted in a predictable increase in flow volume, with the exception of Pumpkin River and Blackwater River in 2008. Both rivers had a greater annual flow volume per inch of rainfall in 2008 than in other years. The high flow volume per inch of rainfall was likely due to the spatial variation in rainfall during Tropical Storm Fay, which was probably not accurately represented by the rain gage used in the comparison. The total annual flow per inch of rainfall in the Faka Union River in 2014 was less than in previous years and may be attributable to restoration efforts, mainly the plugging of Prairie Canal.

Faka Union River was the dominant (greater than 80 percent of monitored flow) contributor of freshwater to the estuary during the wet season in all water years. The next largest contributors to wet season flow were Little Wood River in 2008, East River in 2011 and 2014, and Blackwater River in 2012 and 2013. Pumpkin River was the smallest (less than 1 percent) contributor of wet season flow in all water years. No changes in the relative contributions of freshwater during the wet season were observed during the study.

Faka Union River contributed all of the streamflow to the estuary during the dry season in 2011, but contributed no positive flow during 2008 and 2014. Blackwater and Little Wood Rivers always had net negative flow during the dry season. Blackwater River had the highest percentage of time with negative flows; total monthly flows were negative 7-10 months of the year during 2008 and 2011-14. The percentage of positive flow during the dry season was high for East River and Pumpkin River in 2014. East River had the greatest flow during the dry season in 2014; only 1 month of net negative flow occurred in 2014 compared to 6 months in 2011 and 7 months in 2008. The increase in freshwater flow at East River during the dry season is potentially linked to restoration efforts.

The highest annual mean salinity recorded in the Ten Thousand Islands estuary occurred in 2011, corresponding with the lowest annual rainfall and flow volume. Data collection did not begin at Palm River until 2012. The highest annual mean salinities for all water years occurred at the Faka Union Boundary, which is located closest to the Gulf of Mexico. The highest instantaneous salinity value recorded was 43.4 ppt at Pumpkin River on May 26 and 27, 2008. The lowest annual mean salinities occurred at Faka Union River, which also had the greatest flow volume. The lowest instantaneous salinity value during the study (0.2 ppt) was recorded at Faka Union River on numerous days in September 2006.

The sites to the west of the Faka Union River had higher salinities on average than Faka Union River and East River, indicating less freshwater is received to the west. The highest percentage of salinity values greater than or equal to $35 \mathrm{ppt}$ (full seawater) at the tidal tributaries occurred in 2011 at Pumpkin River (57.0 percent) and Blackwater River (50.7 percent), corresponding with the lowest annual rainfall and lowest annual flow volume during the study. The highest percentage of salinities less than 35 ppt occurred during 2013, corresponding with the highest rainfall totals and highest flow volumes. Faka Union River had the lowest percentage of salinity values greater than $35 \mathrm{ppt}$, ranging from 11.1 percent in 2013 to 29.6 percent in 2008 .

The greatest range in monthly mean salinities occurred at Faka Union River. The lowest monthly mean salinities occurred at Faka Union River and East River. Additionally, salinities began to decrease at Faka Union River and East River before the sites west of Faka Union. The lowest monthly mean salinities occurred at Faka Union River in September 2006. The highest monthly mean salinities occurred at Pumpkin River in May 2008. The monthly mean salinity was higher at Pumpkin River in May 2008 than at Faka Union Boundary, even though the Pumpkin River is farther from the Gulf of Mexico. Faka Union Boundary had the smallest range in monthly mean salinity, as was expected because it is near the Gulf of Mexico. The next lowest range in salinity occurred at Pumpkin River, followed by Little Wood River, indicating decreased freshwater input at these sites. Patterns in salinity indicate that freshwater is not evenly distributed to the Ten Thousand Islands. Annual rainfall accounted for 89 to 94 percent of the variance in annual mean salinity. No changes in patterns between rainfall and annual mean salinity were observed during the study period.

Flows that would have reached the tributaries in the study area continued to be directed into the Faka Union Canal during the time of the study. East River receives more freshwater than many of the other tributaries. Restoration efforts may have had effects at East River and Faka Union Canal in 2014, but minimal data were available at the time of publication. 


\section{References Cited}

Booth, A.C., Soderqvist, L.E., and Berry, M.C., 2014, Flow monitoring along the western Tamiami Trail between County Road 92 and State Road 29 in support of the Comprehensive Everglades Restoration Plan, 2007-2010: U.S. Geological Survey Data Series 831, 24 p. + appendix tables A-A3 (Excel), accessed June 9, 2015, at http://dx.doi. org/10.3133/ds831.

Chuirazzi, K., Duever, M., and Abtew, W., 2015, Appendix 2-1: Annual permit report for the Picayune Strand Restoration Project, Phase 1-Prairie Canal Backfill and Road Removal component: West Palm Beach, Fla., South Florida Water Management District, accessed November 2015 at http://www.sfwmd.gov/portal/page/portal/pg_grp_sfwmd_ sfer/portlet_prevreport/2014_sfer/v3/appendices/v3_app2-1. pdf.

Godin, G., 1972, The analysis of tides: Toronto, University of Toronto Press, 264 p.

Levesque, V.A., and Oberg, K.A., 2012, Computing discharge using the index velocity method: U.S. Geological Survey Techniques and Methods 3-A23, 148 p. [Also available at http://pubs.usgs.gov/tm/3a23/.]

McCoy, J., 1972, Hydrology of western Collier County, Florida: Florida Geological Survey, Report of Investigations, Number 63, accessed July 2015 at http://aquaticcommons. org/1861/1/Collier.pdf.

Simpfendorfer, C.A., Wiley, T.R., and Yeiser, B.G., 2010, Improving conservation planning for an endangered sawfish using data from acoustic telemetry: Biological Conservation, v. 143, no. 6, p. 1460-1469, accessed June 9, 2016, at http://dx.doi.org/10.1016/j.biocon.2010.03.021.

Soderqvist, L.E., and Patino, Eduardo, 2010, Seasonal and spatial distribution of freshwater flow and salinity in the Ten Thousand Islands estuary, Florida, 2007-2009: U.S. Geological Survey Data Series 501, 24 p. [Also available at http://pubs.usgs.gov/ds/501/.]

South Florida Water Management District, 2013, Big Cypress Basin, Operation of Water Control Structures May 2013, accessed December 2015 at http://my.sfwmd.gov/portal/ page/portal/xrepository/sfwmd_repository_pdf/pamphlet_ bcb_ops_schedule.pdf.
South Florida Water Management District, 2015a, Picayune pump station delivers first gallon of water for restoration, accessed November 2015, at http://www.sfwmd.gov/ portal/page/portal/xrepository/sfwmd_repository_pdf/ nr_2015_0630_picayune_update.pdf.

South Florida Water Management District, 2015b, SFWMD Average Rainfall (30 Year: 1981-2010), accessed December 2015 at http://www.sfwmd.gov/portal/page/portal/ xweb $\% 20$ weather/rainfall $\% 20$ historical $\% 20 \% 28$ normal $\% 20$ florida $\% 20$ annual $\% 20$ rainfall $\% 20$ map $\% 29$.

South Florida Water Management District, 2015c, DBHYDRO menu, accessed December 1, 2015, at http://www.sfwmd. gov/dbhydroplsq1/show_dbkey_info.main_menu.

U.S. Army Corps of Engineers, 1998, Central and Southern Florida Ecosystem Restoration Project Letter ReportTamiami Trail culverts, accessed February 2005 at http:// www.saj.usace.army.mil/projects/tamtrep.htm.

U.S. Army Corp of Engineers, 2004, Picayune Strand Restoration Project (formerly Southern Golden Gate Estates Ecosystem Restoration): Final Integrated Project Implementation Report and Environmental Impact Statement, Jacksonville, Fla., 414 p.

U.S. Army Corp of Engineers, 2008, Picayune Strand Restoration Facts \& Information, accessed October 2008 at http:// www.evergladesplan.org/docs/fs_picayune_jan_2008.pdf.

U.S. Fish and Wildlife Service, 2008, Ten Thousand Islands National Wildlife Refuge, accessed September 2015 at http://www.fws.gov/southeast/pubs/facts/tticon.pdf.

U.S. Geological Survey, 2010, Office of Surface Water Technical Memorandum No. 2010.08, 37 p.

U.S. Geological Survey, 2015, National Water Information System-Web interface, accessed September 4, 2015, at http://dx.doi.org/10.5066/F7P55KJN.

Wagner, R.J., Boulger, R.W., Jr., Oblinger, C.J., and Smith, B.A., 2006, Guidelines and standard procedures for continuous water-quality monitors - Station operation, record computation, and data reporting: U.S. Geological Survey Techniques and Methods 1-D3, $51 \mathrm{p}$. [Also available at http://pubs.usgs.gov/tm/2006/tm1D3/.] 
Publishing support provided by:

Lafayette Publishing Service Center

For more information concerning this publication, contact: Director

U.S. Geological Survey

Caribbean-Florida Water Science Center

4446 Pet Lane, Suite 108

Lutz, FL 33559

(813) 498-5000

Or visit the Florida Water Science Center Web site at: http://fl.water.usgs.gov/ 
